\title{
DEPLETED AND NATURAL URANIUM: CHEMISTRY AND TOXICOLOGICAL EFFECTS
}

\author{
Elena S. Craft, ${ }^{1}$ Aquel W. Abu-Qare, ${ }^{2}$ Meghan M. Flaherty, ${ }^{3}$ Melissa C. Garofolo, ${ }^{4}$ \\ Heather L. Rincavage, ${ }^{4}$ Mohamed B. Abou-Donia ${ }^{4}$ \\ ${ }^{1}$ Nicholas School of the Environment and Earth Sciences, Duke University, Durham, \\ North Carolina, USA \\ ${ }^{2}$ Department of Pharmacology and Cancer Biology, Duke University, Durham, North \\ Carolina, USA \\ ${ }^{3}$ Nicholas School of the Environment and Earth Sciences and Department of Biological \\ Chemistry and Chemistry, Duke University, Durham, North Carolina, USA \\ ${ }^{4}$ Nicholas School of the Environment and Earth Sciences and Department of Pharmacology \\ and Cancer Biology, Duke University, Durham, North Carolina, USA
}

\begin{abstract}
Depleted uranium (DU) is a by-product from the chemical enrichment of naturally occurring uranium. Natural uranium is comprised of three radioactive isotopes: ${ }^{238} \mathrm{U},{ }^{235} \mathrm{U}$, and ${ }^{234} \mathrm{U}$. This enrichment process reduces the radioactivity of DU to roughly $30 \%$ of that of natural uranium. Nonmilitary uses of DU include counterweights in airplanes, shields against radiation in medical radiotherapy units and transport of radioactive isotopes. DU has also been used during wartime in heavy tank armor, armor-piercing bullets, and missiles, due to its desirable chemical properties coupled with its decreased radioactivity. DU weapons are used unreservedly by the armed forces. Chemically and toxicologically, DU behaves similarly to natural uranium metal. Although the effects of DU on human health are not easily discerned, they may be produced by both its chemical and radiological properties. DU can be toxic to many bodily systems, as presented in this review. Most importantly, normal functioning of the kidney, brain, liver, and heart can be affected by DU exposure. Numerous other systems can also be affected by DU exposure, and these are also reviewed. Despite the prevalence of DU usage in many applications, limited data exist regarding the toxicological consequences on human health. This review focuses on the chemistry, pharmacokinetics, and toxicological effects of depleted and natural uranium on several systems in the mammalian body. A section on risk assessment concludes the review.
\end{abstract}

Interest in depleted uranium (DU) is rapidly increasing as researchers realize its many potential military and civilian applications. Uranium, a naturally occurring heavy metal, is found in all soils, waters and rocks. Natural uranium is comprised of three radioactive isotopes: ${ }^{238} U,{ }^{235} \mathrm{U}$, and ${ }^{234} \mathrm{U}$. Of these, ${ }^{235} \mathrm{U}$ is of particular interest due to its ability to sustain nuclear chain reactions. However, in naturally occurring uranium ${ }^{235} \mathrm{U}$ only accounts for $0.72 \%$ isotopic composition. Therefore, techniques have been developed in which uranium ore is chemically enriched, increasing the concentration of ${ }^{235} U$ to $2-4 \%$ (ATSDR, 1999). The uranium that remains after processing, commonly called depleted uranium, has decreased levels of ${ }^{235} \mathrm{U}$. DU, although having all the chemical and biological properties of naturally occurring uranium, is significantly less radioactive. The high density of uranium, combined with low radioactivity, makes DU especially attractive for use in military armor and in armor penetrators, and was used recently during the Gulf and the Balkans wars (Abu-Qare \& Abou-Donia, 2002; Bolton \& Foster, 2002, Bleise et al., 2003). Civilian uses of DU include counterweights in airplane construction, shields for irradiation units in hospitals, and containers for transport of radioactive sources. Small quantities of DU are used in the formation of porcelains, glasses, and catalysts. The military and the civilian uses of depleted uranium has environmental and health implications (Cantaluppi \& Degetto, 2000).

This review updates earlier literature on natural and depleted uranium presenting their chemistry, pathways of exposure, behavior within the body, and apparent adverse health effects (Figure 1). Finally, a risk assessment for DU has been made, including exposure limits and hazardous chemical formulas.

All authors contributed equally to this report.

Address correspondence to M. B. Abou-Donia, Pharmacology and Cancer Biology, C173A Levine Science Research Center, Box 3813, Duke University Medical Center, Durham, NC 27710, USA. E-mail: donia@acpub.duke.edu 


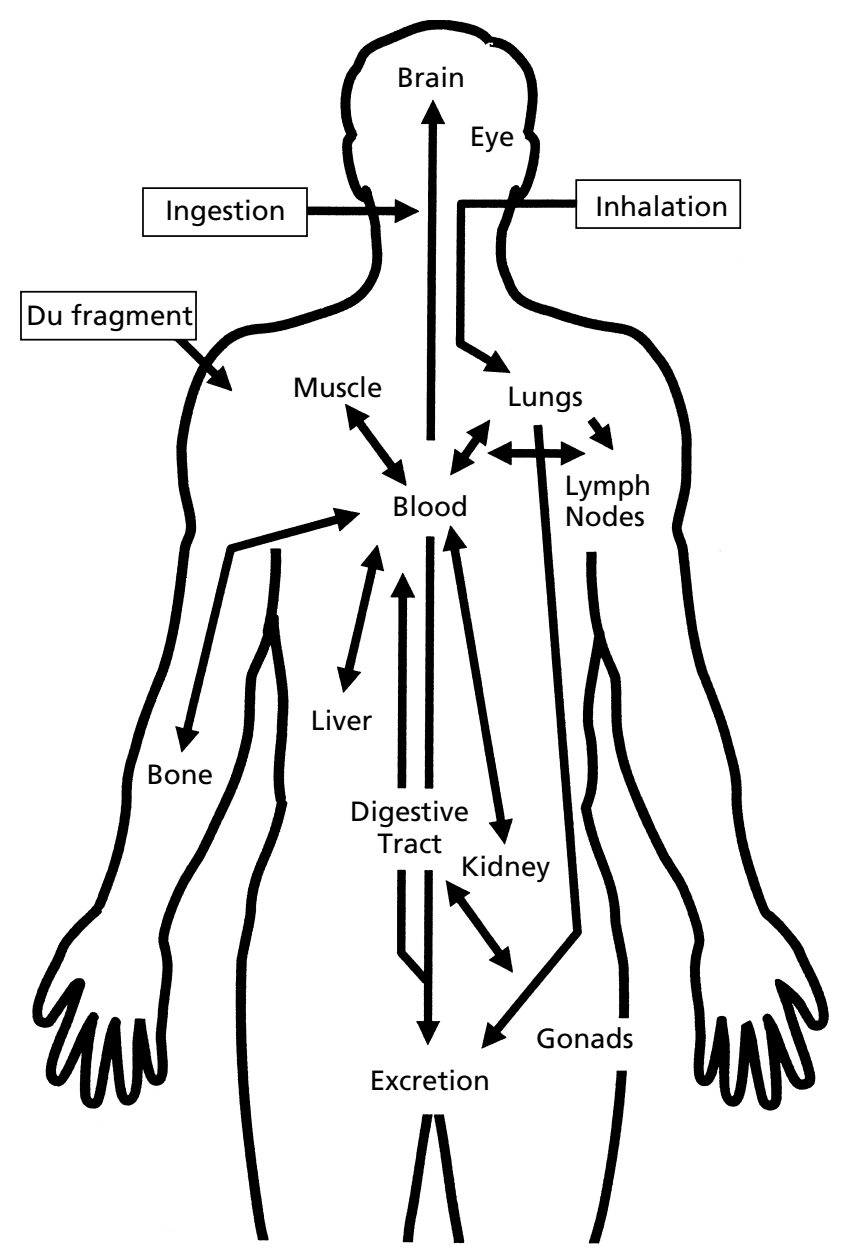

FIGURE 1. Body systems impacted by DU exposure.

\section{SOURCES OF URANIUM}

In 1789, Martin Heinrich Klaproth discovered a new element, uranium, which he named after the newly discovered planet Uranus (Soloveichik, 1993). Fifty years later, in 1841, E. M. Péligot found that the uranit discovered by Klaproth was not metallic uranium but uranium dioxide, $\mathrm{UO}_{2}$. True elemental uranium was obtained by thermally reducing anhydrous uranium tetrachloride, $\mathrm{UCl}_{4}$, in the presence of potassium (Grey, 1993). A new process for producing metallic uranium (>99\% uranium), involving the electrolysis of sodium uranyl chloride, was developed by $\mathrm{H}$. Moissan in the 1890s (Clark et al., 1997; Peehs et al., 1996).

The enrichment process generally involves processing uranium ore into uranium oxide $\left(\mathrm{U}_{3} \mathrm{OX}\right)$ and then fluorinating it to $\mathrm{UF}_{6}$. This $\mathrm{UF}_{6}$ gas, containing all three isotopes, is then passed through a long series of columns through which the ${ }^{234} \mathrm{U}$ and ${ }^{235} \mathrm{U}$ pass more quickly than ${ }^{238} \mathrm{U}$. The enriched $U_{6}$ is typically converted to uranium metal for a nuclear reactor fuel. The depleted $U_{6}$ is either converted to uranium metal for a variety of civilian or military uses, or is stored for future use. Poorly enriched uranium (2-4\%) is used in civilian nuclear power reactors, while highly enriched uranium $(>90 \%)$ is used in special research reactors, nuclear submarine reactor cores, and nuclear weapons. DU is used as (1) radiation shielding, (2) for missile projectiles, (3) as target elements in plutonium production reactors, (4) for gyroscope components, and (5) as counterweights or stabilizers in aircrafts. DU is chemically identical to natural and enriched uranium, although it is approximately $40 \%$ less radioactive than the naturally occurring metal (ATSDR, 1999). 
TABLE 1. Naturally Occurring Uranium Ores

\begin{tabular}{ll}
\hline Ore & Composition \\
\hline Uraninite & $\mathrm{UO}_{2}+\mathrm{UO}_{3}$ \\
Pitchblende & $\mathrm{UO}_{2}+\mathrm{UO}_{3}$ \\
Carnotite & $\mathrm{K}_{2} \mathrm{O} \cdot 2 \mathrm{U}_{2} \mathrm{O}_{3} \cdot \mathrm{V}_{2} \mathrm{O}_{5} \cdot 3 \mathrm{H}_{2} \mathrm{O}$ (uranium potassium vanadate) \\
Autunite & $\mathrm{Ca}\left(\mathrm{UO}_{2}\right)_{2}\left(\mathrm{PO}_{4}\right)_{2} \cdot 10 \mathrm{H}_{2} \mathrm{O}$ \\
Torbernite & $\mathrm{Cu}\left(\mathrm{UO}_{2}\right)_{2}\left(\mathrm{PO}_{4}\right)_{2} \cdot 10 \mathrm{H}_{2} \mathrm{O}$ \\
Coffinite & $\mathrm{U}\left(\mathrm{SiO}_{4}\right)_{1-x}(\mathrm{OH})_{4 \times}($ uranium silicate) \\
Tyuyamunite & $\mathrm{Ca}\left(\mathrm{UO}_{2}\right)_{2}\left(\mathrm{VO}_{4}\right)_{2} \cdot 5-8 \mathrm{H}_{2} \mathrm{O}$ (uranium calcium vanadate) \\
\hline
\end{tabular}

Note. Adapted from ASTDR (1999).

Uranium makes up approximately $2-4 \mathrm{mg} / \mathrm{kg}$ of the earth's crust (ATSDR, 1999). It is more plentiful than silver or tin, with an abundance equal to that of molybdenum or arsenic. Although in nature there are more than 100 different uranium ores, uranium typically occurs as the mixed oxide $\mathrm{U}_{3} \mathrm{O}_{8}$, in amorphous (pitchblende) or crystalline forms (uraninite). Additional sources of uranium include torbernite $\left(\mathrm{Cu}\left(\mathrm{UO}_{2}\right)_{2}\left(\mathrm{PO}_{4}\right)_{2} \cdot n \mathrm{H}_{2} \mathrm{O}\right)$ and carnotite $\left(\mathrm{K}_{2}\left(\mathrm{UO}_{2}\right)_{2}\left(\mathrm{VO}_{4}\right)_{2} \cdot 3 \mathrm{H}_{2} \mathrm{O}\right)$, as well as those listed in Table 1. Large deposits of uranium were discovered in the United States, Canada, South Africa, and Australia. The greatest concentrations of uranium in the United States are located in the Western states of Colorado, Arizona, Wyoming, Texas, Utah, and New Mexico (Lide, 1994).

\section{CHEMISTRY}

\section{Isotopic Forms}

Uranium, having the atomic number 92 and an atomic mass of $238.03 \mathrm{~g} / \mathrm{mol}$, can be transformed into the stable element lead $(\mathrm{Pb})$ via many intermediate stages involving the emission of $\alpha$ and $\beta$ radiation (Soloveichik, 1993). There are 19 isotopes of uranium, having radioactive half-lives $\left(T_{\mathrm{p}}\right)$ ranging from $1 \mu \mathrm{s}\left({ }^{222} \mathrm{U}\right)$ to $4.468 \times 10^{9} \mathrm{yr}\left({ }^{238} \mathrm{U}\right)$ and atomic masses ranging from 218 to $242 \mathrm{~g} / \mathrm{mol}$. Natural uranium contains a mixture of three isotopes: ${ }^{238} \mathrm{U}(99.2830 \%$, $\left.T_{p}=4.47 \times 10^{9} \mathrm{yr}, 4.15 \mathrm{MeV} \alpha\right),{ }^{235} \mathrm{U}\left(0.7110 \%, T_{p}=7.08 \times 10^{8} \mathrm{yr}, 4.29 \mathrm{MeV} \alpha\right)$, and ${ }^{234} \mathrm{U}$ $\left(0.0054 \%, T_{p}=2.45 \times 10^{5} \mathrm{yr}, 4.78 \mathrm{MeV} \alpha\right)($ Table 2$)$. These three isotopes are all $\alpha$-emitters with decay series, terminating with the nonradioactive isotopes ${ }^{206} \mathrm{~Pb}$ and ${ }^{207} \mathrm{~Pb}$ (Clark et al., 1997) (Figure 2).

DU is $99.8 \%{ }^{238} \mathrm{U}$, and an $\alpha$ and weak $\gamma$ emitter with a $T_{\mathrm{p}}$ of approximately $4.5 \times 10^{9} \mathrm{yr} .{ }^{238} \mathrm{U}$ decays into three short-lived progeny: thorium ${ }^{(234} \mathrm{Th}$ ), with a $T_{\mathrm{p}}$ of $24.1 \mathrm{~d}$; protactinium $\left.{ }^{234 \mathrm{~m}} \mathrm{Pr}\right)$, which has a $T_{p}$ of $1.2 \mathrm{~min}$; and ${ }^{234} \mathrm{Pr}$, which has a $T_{\mathrm{p}}$ of $6.7 \mathrm{~h}$. All three of these progeny are $\beta$ and weak $\gamma$ emitters, with both protactinium species decaying into ${ }^{234} U$. The ${ }^{234} U$ isotope, which makes up $0.0006 \%$ weight of $\mathrm{DU}$, is an $\alpha$ and weak $\gamma$ emitter with a $T_{\mathrm{p}}$ of $2.4 \times 10^{5} \mathrm{yr}$. The ${ }^{234} \mathrm{U}$ decay products include ${ }^{230} \mathrm{Th}$, which has a $T_{p}$ of $7.7 \times 10^{4} \mathrm{yr}$. These long half-lives result in a negligible build-up of $\alpha$

TABLE 2. Percentage and Radioactive Properties of Naturally Occurring Isotopes of Uranium

\begin{tabular}{lllll}
\hline Isotope & Weight $^{a}$ & Radioactivity $^{a}$ & Alpha energies (MeV) & Half-life (yr) \\
\hline U-234 & 0.0055 & 48.9 & $4.776(72.5 \%)$ & $2.45 \times 10^{5}$ \\
U-235 & 0.720 & 2.2 & $4.597(5 \%)$ & $7.04 \times 10^{8}$ \\
& & $4.395(55 \%)$ & \\
& & $4.370(6 \%)$ & $4.364(11 \%)$ \\
U-238 & & $4.216(5.7 \%)$ & $4.46 \times 10^{9}$ \\
\end{tabular}

${ }^{a}$ Percent of total uranium in rocks and soil (Fulco et al., 2000). 


\section{${ }^{235} \mathrm{U}$ decay series}

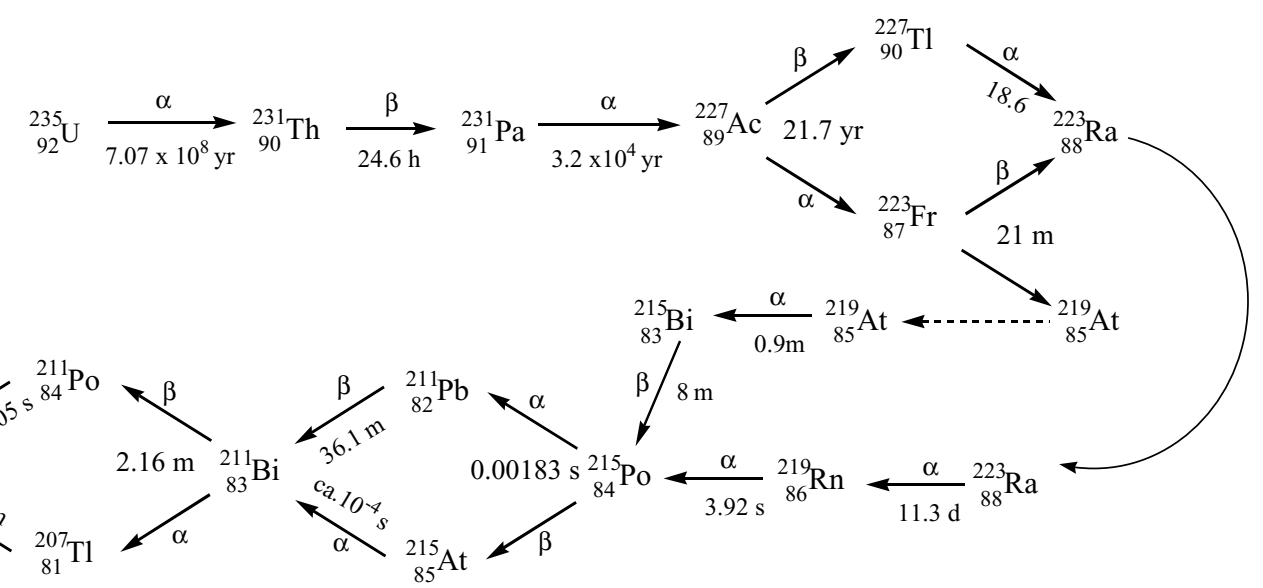

\section{${ }^{234} \mathrm{U}$ and ${ }^{283} \mathrm{U}$ decay series}

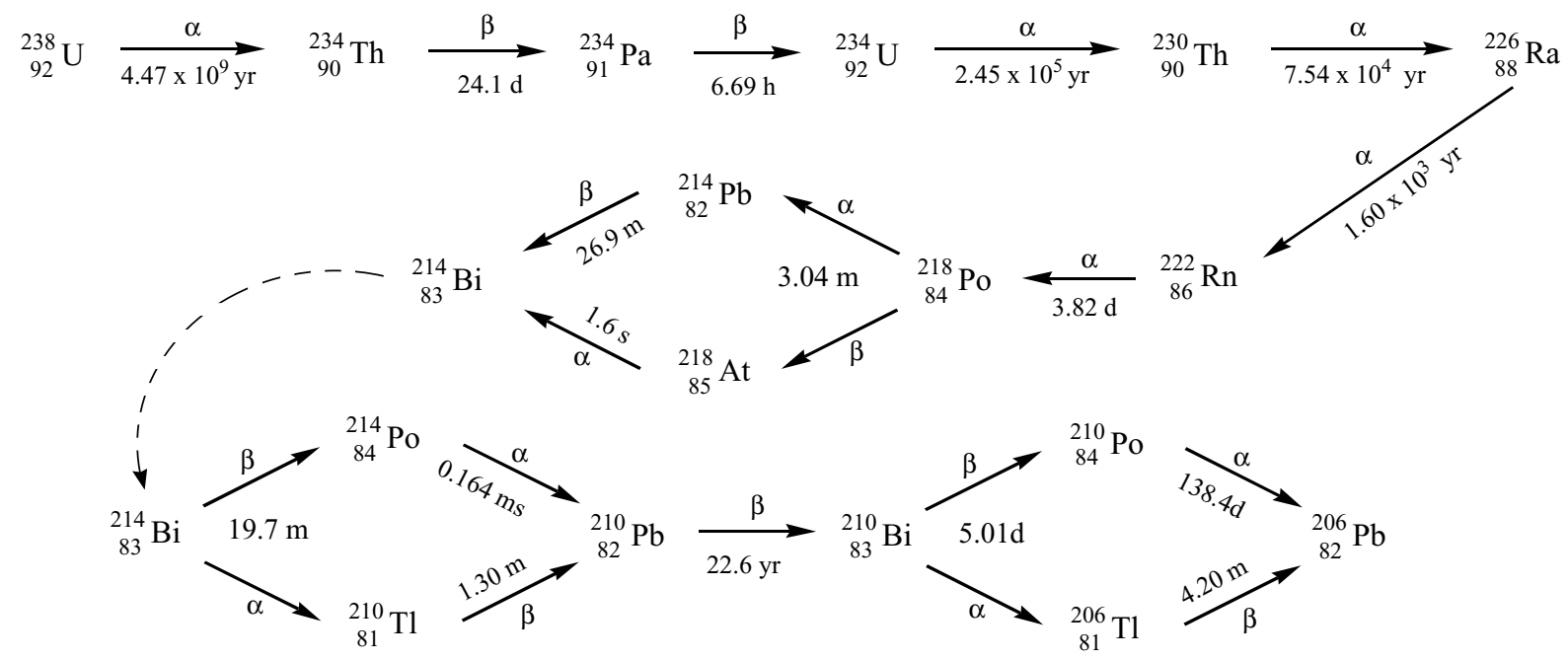

FIGURE 2. Decay series for the naturally occurring uranium isotopes (adapted from Clark et al., 1997). U, uranium; Th, thorium; Pa, protactinium; Ac, actinium; Tl, thallium; Fr, francium; Ra, radium; At, astatine; Bi, bismuth; Rn, radon; Po, polonium; Pb, lead.

activity from ${ }^{230} \mathrm{Th}$ in DU samples. The ${ }^{235} \mathrm{U}$ isotope, which makes up $0.2 \%$ of DU, has a $T_{\text {p }}$ of $7.0 \times 10^{8} \mathrm{yr} .{ }^{235} \mathrm{U}$ is an $\alpha$ and weak $\gamma$ emitter and decays into ${ }^{231} \mathrm{Th}$, which has a $T_{\mathrm{p}}$ of $25.5 \mathrm{~h}$ and is a $\beta$ and weak $\gamma$ emitter. DU also contains a number of non-naturally occurring isotopes, including ${ }^{236} \mathrm{U}$. This isotope makes up $0.0003 \%$ of $\mathrm{DU}$, and is an $\alpha$ emitter with a $T_{\mathrm{p}}$ of $2.3 \times 10^{7} \mathrm{yr}$. Other impurities may include trace amounts of plutonium $\left({ }^{238-239} \mathrm{Pu}\right)$, americium $\left({ }^{241} \mathrm{Am}\right)$, neptunium $\left({ }^{237} \mathrm{Nu}\right)$, and technetium $\left({ }^{99} \mathrm{Tc}\right)$. It is estimated that these impurities add less than $1 \%$ to the concentration and are therefore inconsequential from a radiological or chemical toxicity standpoint (Fulco et al., 2000) (Table 3). 
TABLE 3. Isotopic Composition of U.S. Government DU Containing Munitions

\begin{tabular}{lll}
\hline Isotope & Percentage by weight & Isotopic activity $\left(\mu \mathrm{C} / \mathrm{g}_{\mathrm{DU}}\right)$ \\
\hline $\mathrm{U}-234$ & $0.0006 \%$ & $3.7 \times 10^{-2}$ \\
$\mathrm{U}-235$ & $0.2 \%$ & $4.3 \times 10^{-3}$ \\
$\mathrm{U}-236$ & $0.0003 \%$ & $2.0 \times 10^{-4}$ \\
$\mathrm{U}-238$ & $99.8 \%$ & $3.4 \times 10^{-1}$ \\
\hline
\end{tabular}

\section{Chemical Properties}

Uranium, one of the densest metals $\left(19.07 \mathrm{~g} \cdot \mathrm{cm}^{-3}\right.$ at $\left.25^{\circ} \mathrm{C}\right)$, is silvery, ductile, and malleable (Table 4). It is highly electropositive, resembling magnesium, and tarnishes rapidly upon exposure to air. As a hard Lewis acid, elemental uranium is extremely difficult to reduce. The most common method includes reacting uranium oxides $\left(\mathrm{UO}_{2}\right.$ or $\left.\mathrm{UO}_{3}\right)$ with strongly electropositive elements such as $\mathrm{Ca}, \mathrm{Mg}$, or $\mathrm{Na}$ [Eqs. (1)-(7)]. Other techniques for isolating elemental uranium include reducing uranium halides with electropositive metals ( $\mathrm{Li}, \mathrm{Na}, \mathrm{Mg}$, $\mathrm{Ca}$, and $\mathrm{Ba}$ ), electrodeposition of halides from molten salt baths, and decomposition of uranium halides via the van Arkel-de Boer method.

$$
\begin{aligned}
& \mathrm{UO}_{3}+6 \mathrm{Na} \rightarrow \mathrm{U}(0)+3 \mathrm{Na}_{2} \mathrm{O} \\
& \mathrm{UO}_{3}+3 \mathrm{Mg} \rightarrow \mathrm{U}(0)+3 \mathrm{MgO} \\
& \mathrm{UO}_{2}+2 \mathrm{Ca} \rightarrow \mathrm{U}(0)+2 \mathrm{CaO} \\
& \mathrm{UO}_{2}+4 \mathrm{Na} \rightarrow \mathrm{U}(0)+2 \mathrm{Na}_{2} \mathrm{O} \\
& \mathrm{UCl}_{4}+2 \mathrm{Ca} \rightarrow \mathrm{U}(0)+2 \mathrm{CaCl}_{2} \\
& \mathrm{UF}_{4}+2 \mathrm{Ca} \rightarrow \mathrm{U}(0)+2 \mathrm{CaF}_{2} \\
& \mathrm{UF}_{4}+2 \mathrm{Mg} \rightarrow \mathrm{U}(0)+2 \mathrm{MgF}_{2}
\end{aligned}
$$

Uranium is the fourth element in the actinide series (Clark et al., 1997), and has five oxidation states: $+2,+3,+4,+5$, and +6 (Lide, 1994). Among these five oxidation states, only the +4 and +6 are stable enough to be of general importance. Aqueous solutions of uranium(III), a potent reducing agent, have been prepared and are readily air oxidized to the +4 state. Uranium(V) rapidly dissociates

TABLE 4. Main Properties of Uranium

\begin{tabular}{ll}
\hline Property & Uranium \\
\hline Atomic number & 92 \\
Isotopes & 22 \\
Most stable isotope & 238 \\
Electronic configuration [Rn] & \\
$\quad 7 s$ & 2 \\
$\quad 6 d$ & 1 \\
$5 f$ & 3 \\
Oxidation states & $2-6$ \\
Most stable & 4,6 \\
Metal radius (pm) & 156 \\
Configuration of the $\mathrm{M}^{3+}$ ions $[\mathrm{Rn}]$ & $f^{3}$ \\
m.p. $\left({ }^{\circ} \mathrm{C}\right)$ & 1130 \\
b.p. $\left({ }^{\circ} \mathrm{C}\right)$ & 3930 \\
Density $\left(\mathrm{g} \mathrm{cm}^{-1}\right)$ & 19.05 \\
$\delta H_{\text {fus }}\left(\mathrm{kJ} \mathrm{mol}{ }^{-1}\right)$ & 12.6 \\
$\delta H_{\text {vap }}\left(\mathrm{kJ} \mathrm{mol}{ }^{-1}\right)$ & 417 \\
\hline
\end{tabular}

Note. Adapted from Soloveichik (1993). 
into both the +4 and +6 states in the presence of water or hydrolytic compounds (Clark et al., 1997). The coordination chemistry of uranium depends on a number of factors, including the oxidation state of the central metal ion, and the ligands to which it is coordinated (Table 5). The relatively stable tetravalent uranium complexes often come in the form of hydroxides, hydrated fluorides, and phosphates. Hexavalently coordinated uranium is significantly more stable than uranium complexes with other coordination numbers (ATSDR, 1999). The diverse coordination chemistry of uranium, in conjunction with a number of other factors including atmospheric pressure and temperature, allows uranium to adopt three crystalline modifications: orthorhombic, tetragonal, or body-centered cubic. These factors, in conjunction with its ability to alloy itself to other metals, allow uranium to have an incredibly diverse array of structural and physical characteristics. Uranium is chemically reactive and combines directly with most elements. As previously mentioned, uranium tarnishes upon exposure to air as the surface of the metal is rapidly converted first into a yellow and subsequently a black, nonprotective film. Powder uranium is frequently pyrophoric (Cotton et al., 1999), a property that is of special relevance when considering the health effects associated with the use of DU in munitions and armor, since the impact of a DU penetrator on a target produces both DU dust and aerosol particles. The burning of DU-containing objects, which also produces DU aerosols, occurs at extremely high temperatures, resulting in the oxidation of uranium metal into a series of complex oxides, predominately depleted triuranium octaoxide $\left(\mathrm{U}_{3} \mathrm{O}_{8}\right)$, DU dioxide $\left(\mathrm{UO}_{2}\right)$, and DU trioxides $\left(\mathrm{UO}_{3}\right)$ (Fulco et al., 2000). Upon weathering, the nonoxidized small particles and surfaces of remaining uranium metal will also slowly oxidize to those three DU oxides over time. The reaction of uranium with water can be complex; Boiling water forms $\mathrm{UO}_{2}$ and hydrogen, with the latter reacting with the metal to form a hydride, resulting in disintegration. Uranium dissolves rapidly in hydrochloric acid (leaving a black residue) and in nitric acid, but slowly in sulfuric, phosphoric, or hydrofluoric acids. Uranium is unaffected by alkaline solutions. An important reaction of uranium is that with hydrogen, forming the hydride, a useful starting material for the synthesis of uranium compounds (Cotton et al., 1999).

TABLE 5. Coordination Numbers and Polyhedra of Uranium

\begin{tabular}{|c|c|c|c|}
\hline Oxidation state & Coordination number & Coordination polyhedron & Examples of compounds \\
\hline+6 & $\begin{array}{l}6 \\
7 \\
8\end{array}$ & $\begin{array}{l}\text { Octahedron } \\
\text { Pentagonal bipyramid } \\
\text { Hexagonal bipyramid }\end{array}$ & $\begin{array}{l}\mathrm{U}(\mathrm{OMe})_{6}, \text { trans }-\mathrm{UO}_{2} \mathrm{Cl}_{2}\left(\mathrm{OPPh}_{3}\right) \\
\mathrm{K}_{3} \mathrm{UO}_{2} \mathrm{~F}_{5},\left[\mathrm{UO}_{2} \mathrm{Cl}_{2}(\mathrm{acac})_{2}\right] \cdot \text { Hacac } \\
\mathrm{UO}_{2}\left(\mathrm{NO}_{3}\right)_{2}\left(\mathrm{H}_{2} \mathrm{O}\right)_{2}\end{array}$ \\
\hline+5 & $\begin{array}{l}6 \\
8\end{array}$ & $\begin{array}{l}\text { Octahedron } \\
\text { Cube }\end{array}$ & $\begin{array}{l}\mathrm{Cs}\left(\mathrm{UF}_{6}\right) \\
\mathrm{Na}_{3}\left[\mathrm{UF}_{8}\right]\end{array}$ \\
\hline \multirow[t]{6}{*}{+4} & $\begin{array}{l}4 \\
5 \\
6\end{array}$ & $\begin{array}{l}\text { Tetrahedron } \\
\text { Trigonal bipyramid } \\
\text { Octahedron } \\
\text { Trigonal prism }\end{array}$ & $\begin{array}{l}\mathrm{U}(\mathrm{OAr})_{4} \\
\mathrm{U}_{2}\left(\mathrm{NEt}_{2}\right)_{8},\left[\mathrm{Li}(\mathrm{THF})_{4}\right]\left[\mathrm{U}(\mathrm{OAr})_{5}\right] \\
\text { cis- } \mathrm{UCl}_{4} \cdot 2 \mathrm{Ph}_{3} \mathrm{PO}, \text { trans- } \mathrm{UBr}_{4} \cdot 2 \mathrm{Ph}_{3} \mathrm{PO}\end{array}$ \\
\hline & 7 & $\begin{array}{l}\text { Pentagonal bipyramid } \\
\text { Capped octahedron }\end{array}$ & $\begin{array}{l}\mathrm{U}_{4}(\mathrm{dmed})_{8} \\
\mathrm{UBr}_{4}, \mathrm{~K}_{3} \mathrm{UF}_{7}\end{array}$ \\
\hline & 8 & $\begin{array}{l}\text { Dodecahedron } \\
\text { Square antiprism } \\
\text { Cube } \\
\text { Bicapped octahedron }\end{array}$ & $\begin{array}{l}{\left[\mathrm{UCl}\left(\mathrm{tmpo}_{6}\right)_{6} \mathrm{Cl}_{3}\right.} \\
\left.\mathrm{U}\left(\mathrm{S}_{2} \mathrm{CNEt}\right)_{2}\right)_{4} \\
\mathrm{U}(\mathrm{acac})_{4} \\
{\left[\mathrm{NEt}_{4}\right]_{4}\left[\mathrm{U}(\mathrm{NCS})_{8}\right]}\end{array}$ \\
\hline & 9 & Tricapped trigonal prism & {$\left[\mathrm{UCl}_{2}\left(\mathrm{Me}_{2} \mathrm{SO}\right)_{6}\right]\left[\mathrm{UCl}_{6}\right]$} \\
\hline & 10 & Bicapped square antiprism & LiUF $_{5}$ \\
\hline & 14 & Bicapped hexagonal antiprism & $\mathrm{U}\left(\mathrm{C}_{2} \mathrm{H}_{3} \mathrm{O}_{2}\right)_{4} \cdot 2 \mathrm{H}_{2} \mathrm{O}, \mathrm{U}\left(\mathrm{MeCO}_{2}\right)_{4}\left[\mathrm{U}\left(\mathrm{BH}_{4}\right)_{4}\right]_{n}$ \\
\hline \multirow[t]{5}{*}{+3} & 5 & Trigonal bipyramid & {$\left[\mathrm{K}(\mathrm{THF})_{2}\right]_{2}\left[\mathrm{U}(\mathrm{NHAr})_{5} \cdot \mathrm{THF}\right.$} \\
\hline & 6 & Octahedron & {$\left[\mathrm{UCl}_{6}\right]^{3-}$} \\
\hline & 8 & Dodecahedron & $\mathrm{UCl}_{3} \cdot \mathrm{DMSO}$ \\
\hline & & Bicapped trigonal prism & $\mathrm{UI}_{3}$ \\
\hline & 9 & Tricapped trigonal prism & $\mathrm{UCl}_{3}$ \\
\hline 0 & 8 & Cube & $\mathrm{U}(\text { bipy })_{4}$ \\
\hline
\end{tabular}

Note. Adapted from Soloveichik (1993). 


\section{Analysis}

The presence and concentration of uranium in biological and environmental samples have been studied using gravimetric, polarographic, and fluorimetric techniques. $\alpha$-Particle counting, delayed neutron emission, mass spectrometry, fission track, and instrumental neutron activation analysis have been also used (Abu-Qare \& Abou-Donia, 2001; Papastefanou, 2002; Uyttenhove et al., 2002; Hodge et al., 2001; Gladney \& Rook, 1975). Traditionally, flourimetry was the most common of these techniques (with a detection limit of $1 \mathrm{ng}$ ); however, because of its $0.05 \mathrm{ng}$ detection limit, a more recent detection method, neutron activation analysis, is also used Although both of these techniques serve to directly quantitate the ${ }^{238} \mathrm{U}$ mass, they don't provide any information on the ${ }^{234} \mathrm{U}:{ }^{238} \mathrm{U}$ and ${ }^{235} \mathrm{U}:{ }^{238} \mathrm{U}$ activity ratios in the sample (Fisenne et al., 1980). This is a particular problem in trying to determine the amount of DU present in a biological system.

This problem has been addressed by using inductively coupled plasma mass spectrometry (ICP-MS) to identify low-level exposures of DU by measuring the isotopic composition of uranium in urine (Hodge et al., 2001; Ejnik et al., 2000). Exposure to DU results in a decreased percentage of ${ }^{235} \mathrm{U}$ in urine samples, resulting in variable measurements to between natural uranium's $0.72 \%$ enrichment and DU's $0.2 \%$ enrichment. ICP-MS has been demonstrated to be sensitive enough to detect these slight variations in isotopic percentages (Krystek \& Ritsema, 2002). One study involved examining urine samples from two groups of test subjects. The first group comprised of people who were suspected to have been exposed to DU, while the second group of subjects had no exposure to DU. The urine samples were dry-ashed at $450^{\circ} \mathrm{C}$, and then wet-ashed with concentrated nitric acid and 30\% hydrogen peroxide. The ash, dissolved in $1 \mathrm{M}$ nitric acid, was analyzed using ICP-MS, and the intensities of the ${ }^{235} \mathrm{U}$ and ${ }^{238} \mathrm{U}$ ions were compared. The group suspected of being exposed to DU had overall urine uranium concentrations greater than $150 \mathrm{ng} / \mathrm{L}$ and ${ }^{235} \mathrm{U}$ readings between $0.20 \%$ and $0.33 \%$. Control subjects, unexposed to DU, had uranium urine concentrations less than $50 \mathrm{ng} / \mathrm{L}$, and ${ }^{235} \mathrm{U}$ percentages of $0.7 \%$ and $1.0 \%$, which is consistent for natural uranium exposure. This ICP-MS technique requires a minimum uranium concentration of $14 \mathrm{ng} / \mathrm{L}$, as sufficient ${ }^{235} \mathrm{U}$ is required to calculate a valid isotopic ratio. Overall, this technique has allowed researchers to test for low-level exposures to DU in a relatively short period of time for the group believed to have been exposed to DU (Ejnik et al., 2000).

In addition to developing techniques for monitoring the presence of DU in biological systems, researchers have also been focusing on developing methods by which shrapnel can be quickly analyzed for DU. This type of detection is important as medical personal may choose to treat those people wounded by DU-containing metal fragments differently than they treat those wounded by non-DU containing shrapnel. A recently developed technique involves treating small shrapnel fragments with an extracting agent such as nitric acid for $5 \mathrm{~min}$ in an ultrasonic cleaner. This process sufficiently solubilizes the metal within the fragments so that colorimetric detection using pyridylazo dye is possible. This technique allows for the detection of a number of other transition metals. However, it can be made specific for DU by using masking agents such as sodium citrate and ethylenediamine tetraacetic acid (EDTA). One of the benefits of this technique is that within 15 min DU can be extracted and detected in metal shrapnel fragments (Kalinich et al., 2000).

\section{PHARMACOKINETICS}

\section{Forms of Absorbed Uranium}

The absorption and distribution of DU depends on the chemical reactions that may take place once the compound has entered the body (Figure 1). Upon entering the body, uranium is involved in a variety of chemical reactions that result in the formation of oxides, hydroxides, and/or carbonates.

The oxides of uranium are some of the most prevalent and physiologically important binary uranium compounds. Numerous oxide phases have been observed and characterized in biological systems including uranium oxides $\left(\mathrm{UO}, \mathrm{UO}_{2}\right), \mathrm{U}_{4} \mathrm{O}_{9}, \mathrm{U}_{3} \mathrm{O}_{7}, \mathrm{U}_{3} \mathrm{O}_{8}$, and $\mathrm{UO}_{3}$, hydrated species such as $\mathrm{UO}_{3} \cdot \times \mathrm{H}_{2} \mathrm{O}$ and the peroxo-complex, $\mathrm{UO}_{4} \cdot \times \mathrm{H}_{2} \mathrm{O}$. Important are also the anionic urinates 
including $\left[\mathrm{U}_{2} \mathrm{O}_{7}\right]^{2-}$ and $\left[\mathrm{U}_{4} \mathrm{O}_{13}\right]^{2-}$. The oxides $\cup_{2}, \cup_{3}$, and $\mathrm{U}_{3} \mathrm{O}_{8}$ are extremely important both industrially and in the nuclear energy cycle, and constitute a majority of the DU compounds in the military (ATSDR, 1999). Some of the preparative techniques for these compounds are outlined later (Clark et al., 1997). Uranium oxides are readily dissolved in bodily fluids, and are thus physiologically significant. Once solubilized, the uranium is free to react with biological molecules and exert adverse effects [Eqs. (8)-(14)].

$$
\begin{aligned}
3 \mathrm{UO}_{2}+1 / 2 \mathrm{O}_{2} & \rightarrow \mathrm{U}_{3} \mathrm{O}_{7} \\
4 \mathrm{UO}_{2}+1 / 2 \mathrm{O}_{2} & \rightarrow \mathrm{U}_{4} \mathrm{O}_{9} \\
3 \mathrm{UO}_{2}+\mathrm{O}_{2} & \rightarrow \mathrm{U}_{3} \mathrm{O}_{8} \\
3 \mathrm{UO}_{3} & \rightarrow \mathrm{U}_{3} \mathrm{O}_{8}+1 / 2 \mathrm{O}_{2} \\
\mathrm{UO}_{3}+\mathrm{H}_{2} & \rightarrow \mathrm{UO}_{2}+\mathrm{H}_{2} \mathrm{O} \\
\mathrm{UO}_{3}+\mathrm{CO} & \rightarrow \mathrm{UO}_{2}+\mathrm{CO}_{2} \\
\mathrm{U}_{3} \mathrm{O}_{8}+5 \mathrm{UO}_{2} & \rightarrow 2 \mathrm{U}_{4} \mathrm{O}_{9}
\end{aligned}
$$

Recent studies indicated that $\mathrm{U}^{4+}$ readily hydrolyzes, even under acidic conditions $(\sim 0.1 \mathrm{M})$. This hydrolysis is complicated by the formation of insoluble hydroxides or oxides, and other gelatinous precipitates. All hydroxides are basic in character and have solubility products in the order of $10^{-42}$ (ATSDR, 1999).

In aqueous systems, uranium(VI) readily forms three monomeric carbonate complexes including $\mathrm{UO}_{2}\left(\mathrm{CO}_{3}\right), \mathrm{UO}_{2}\left(\mathrm{CO}_{3}\right)_{2}{ }^{2-}$, and $\mathrm{UO}_{2}\left(\mathrm{CO}_{3}\right)_{3}{ }^{4-}$. Solubility and spectroscopic data suggest that in solution there are also a number of polymeric species. Ions of actinides are typical hard Lewis acids and display a strong affinity for oxygen-containing donors. Anions of oxygen acids coordinate to the metal via oxygen bridges, usually acting as bidentate ligands. The stability of these complexes decreases in the order $\mathrm{CO}_{3}{ }^{2-}>\mathrm{CH}_{3} \mathrm{CO}_{2}{ }^{-}>\mathrm{SO}_{4}{ }^{2-}>\mathrm{NO}_{3}{ }^{-}$. In addition, it is known that carboxylate anions can precipitate $\mathrm{U}^{4+}(\mathrm{ATSDR}, 1999)$.

\section{Routes of Absorption}

The major sources of DU exposure, and thus the sources available for absorption and distribution in most individuals exposed to DU, are inhalation or ingestion of DU-containing compounds, or embedded DU fragments that have been left in the body (primarily found in soldiers injured by DU shrapnel, stray bullets, and other munitions). In discussing absorption and distribution, this review focuses on the uranium oxides. These oxides, particularly uranium trioxide $\left(\mathrm{UO}_{3}\right)$, triuranium octaoxide $\left(\mathrm{U}_{3} \mathrm{O}_{8}\right)$, and uranium dioxide $\left(\mathrm{UO}_{2}\right)$ are the primary aerosol by-products of exploded DU munitions (OSAGWI, 1998). In addition, other uranium exposure data are mentioned as they pertain to uranium toxicity and biologically significant uranium complexes.

Dermal exposure Percutaneous absorption is one of the routes that uranium can enter the body systemically. However, the amount of uranium absorbed depends on factors such as the solubility of the uranium compound, the length of time of exposure, the size of the area that is exposed, and other physical and physiological conditions.

Several rodent studies have examined the dermal absorption of uranium compounds. De Rey et al. (1983) for instance, used a Vaseline and water vehicle to expose Wistar rats to $0.5-7 \mathrm{~g} / \mathrm{kg}$ body weight uranyl nitrate hexahydrate and $7 \mathrm{~g} / \mathrm{kg}$ body weight ammonium uranyl tricarbonate. Electron microscopy was used in this study to visualize the precise location of uranium within the tissues. Dermally exposed uranyl nitrate, the most soluble of the uranium compounds tested, penetrated into the intracellular space and through the pilosebaceous apparatus. DU exposure resulted in swollen and vacuolated epidermal cells, as well as damage to hair follicles and sebaceous glands (De Rey et al., 1983). After a 15-min exposure, the animals exhibited uranium toxicity in the form of kidney injury, which resulted in weight loss and death in turn. Orcutt (1949a) reported toxicity in 
rats, mice, and guinea pigs following less than $0.1 \%$ dermally absorbed uranium tetrafluoride $\left(\mathrm{UF}_{4}\right)$, uranium tetrachloride $\left(\mathrm{UCl}_{4}\right)$, and uranium trioxide compounds.

Respiratory exposure The absorption of uranium compounds via inhalation is related to the solubility of the compounds, in addition to the site of deposition, the clearance mechanisms available for particle removal, the severity of tissue damage in the respiratory system, and other physical and physiological factors. As previously mentioned, exploded DU munitions may create the aerosol by-products of $\cup_{2}, \cup O_{3}$, and $\mathrm{U}_{3} \mathrm{O}_{8}$ (OSAGWI, 1998). Of these compounds, $\mathrm{UO}_{3}$ is the most soluble in biological fluids, due to its conversion to uranyl hydroxide hydrate and subsequent cation exchange with hydroxyl groups (Stuart et al., 1979). Thus, this compound can be rapidly absorbed systemically via pulmonary alveoli. Because the other uranium oxides, $\mathrm{U}_{3} \mathrm{O}_{8}$ and $\cup_{2}$, are considered to have a medium to slow dissolution, it may take these compounds several weeks or even years to enter the systemic circulation (Fulco et al., 2000).

It is known that only particles that are smaller than $10 \mu \mathrm{m}$ in diameter will reach the inner bronchioles and alveoli of the lung. Exposure to uranium compounds, in the form of aerosols, deposited in the bronchioles and alveoli have a biological $T_{\mathrm{p}}$ in the lungs of approximately $1 \mathrm{yr}$ (Stradling et al., 1989). This is significant, as it has been previously shown that once uranium is deposited in the lungs, it can enter the body systemically and form deposits in bones and other organs. Uranium is also partially excreted through the urine.

Oral exposure A human study examining gastrointestinal absorption of uranyl nitrate in 4 male volunteers, aged $56-78 \mathrm{yr}$, demonstrated that absorption following an overnight fast ranged from $0.3-3.3 \%$ of the total $10.8 \mathrm{mg}$ ingested (Hursh et al., 1969). Another study reported that vomiting, diarrhea, and slight albuminuria resulted from ingestion of $1 \mathrm{~g}$ uranyl nitrate (Stopps \& Todd, 1982). Other reports indicated that absorption of environmental concentrations of uranium $(1.75 \mu \mathrm{g} / \mathrm{d})$ through the gut is $1.8 \%$ (Wrenn et al., 1985).

In general, because DU or DU oxides have slow to medium solubility in vivo, gastrointestinal absorption is not considered a major route of uranium exposure. It is important to note, however, that there is substantial uncertainty in calculating gastrointestinal absorption of uranium. For calculating cancer risks, the U.S. Environmental Protection Agency (EPA) has estimated that approximately 20\% of uranium can be absorbed through the gastrointestinal (GI) tract (U.S. EPA, 1991, 2000). It is believed that human neonatal gastrointestinal absorption of uranium is greater than in the adult because of evidence suggesting that absorption of heavy metals increases during development (Oskarsson et al., 1998)

Following ingestion, rats exhibited significantly lower levels of uranium absorption than other animal species, such as dogs, hamsters, baboons, and neonatal swine (Wrenn et al., 1985). It has been reported that only $0.01-0.07 \%$ of the orally administered uranyl nitrate was absorbed by 2 -d-old rats (ICRP, 1994), whereas a one day-old neonatal swine dosed with 1.5-2.0 mg/kg uranyl nitrate showed an absorption of $34.5 \%$. Fasting and iron deficiency has been demonstrated to increase these absorption rates by 2 - to 3.4 -fold, respectively (ATSDR, 1999).

Embedded DU fragments The use of DU in the Gulf War heightened the awareness of DU exposure, and the issues and adverse health effects associated with it. Soldiers in the Gulf War were exposed to an average of $45 \mathrm{mg}$ DU over the course of their tour (ATSDR, 1999). Most of the DU exposures in this context resulted from shrapnel that were retained in the bodies of some of the veterans following "friendly fire incidents" and/or other accidental exposures. Conventional shrapnel is not generally removed from the body due to excessive tissue damage that may result from its removal. DU shrapnel, however, may be treated using the extracting methods previously mentioned.

\section{Distribution}

Although most of the inhaled, ingested, or percutaneously absorbed uranium is excreted through the urine or feces, different uranium compounds demonstrate selective distribution into certain areas of the body. Among the uranium-containing compounds retained in the body, $85 \%$ of the medium- and slow-dissolving compounds deposit in the bones, where they have a $T_{\mathrm{p}}$ ranging from 180 to $833 \mathrm{~d}$ (Hursh et al., 1969) (Table 6). The remaining 15\% are primarily deposited in the 
TABLE 6. Relative Rates of Dissolution for Biologically Significant Uranium Coordination Complexes

\begin{tabular}{lll}
\hline Type $\mathrm{F}$ (fast) & Type $\mathrm{M}$ (medium) & Type $\mathrm{S}$ (slow) \\
\hline Uranium hexafluoride $\left(\mathrm{UF}_{6}\right)$ & Uranium tetrafluoride $\left(\mathrm{UF}_{4}\right)$ & Uranium dioxide \\
Uranium tetrachloride $\left(\mathrm{UCl}_{4}\right)$ & Uranium trioxide $\left(\mathrm{UO}_{3}\right)$ & Triuranium octaoxide $\left(\mathrm{U}_{3} \mathrm{O}_{8}\right)$ \\
Uranyl fluoride $\left(\mathrm{UO}_{2} \mathrm{~F}_{2}\right)$ & & \\
Uranyl nitrate hexahydrate $\left[\mathrm{UO}_{2}\left(\mathrm{NO}_{3}\right)_{2} \cdot 6 \mathrm{H}_{2} \mathrm{O}\right]$ & & \\
\hline
\end{tabular}

proximal tubules of the kidneys (Hursh et al., 1969). It is the accumulation of uranium in the kidneys that first suggests effects of DU exposure. Small portions of uranium have also been detected in the lungs and liver (Fulco et al., 2000). Figure 3, as reported by Pellmar et al. (1999a), demonstrated the organ distribution of DU following 18 mo of implantation of 4, 10, or 20 DU pellets in SpragueDawley rats. This experiment was repeated using tantalum pellets instead of DU. This allowed the researchers to have a control to which they could compare their results (pellets were $1 \mathrm{~mm}$ diameter by $2 \mathrm{~mm}$ in length, and $99.25 \% \mathrm{DU}$ and $0.75 \%$ titanium by weight) (Pellmar et al., 1999a).

\section{Metabolism and Excretion}

No data are currently available regarding the metabolism or biotransformation of uranium in vivo, for either humans or animals. However, it is known that following absorption, uranium forms soluble complexes with bicarbonates, citrates, and proteins, all of which are present in high concentrations in the body (Cooper et al., 1982). The most common and bioavailable form of uranium is the uranyl ion $\left(\mathrm{UO}_{2}{ }^{2+}\right)$.

Most data on uranium excretion has been obtained from Gulf War veterans who have retained DU fragments in their bodies. The dose of internalized DU is a function of contact time, particle solubility, rate of elimination, and the proximity of embedded fragments to tissues (McDiarmid et al., 2000). McDiarmid et al. (2000) found that urinary excretion of uranium was significantly greater in veterans with implanted DU fragments than in those veterans without DU fragments. In that study, urinary uranium determinations were accomplished by ashing the urine sample, dissolving the specimens in dilute hydrochloric acid, and then passing the samples through a base anionexchange resin. The uranium was eluted with nitric acid, and uranium concentrations were determined using a kinetic phosphorescence analyzer (McDiarmid et al., 2000). Although no adverse health effects were associated with this increased urinary uranium excretion, it was difficult to determine the levels of exposure experienced by these patients.

\section{TOXICOLOGICAL EFFECTS}

\section{Nephrotoxicity}

Renal toxicity has been the hallmark effect of uranium exposure. However, several epidemiological studies have found no increased mortality in uranium workers due to renal disease (Checkoway et al., 1988; Polednak \& Frome, 1981). It has also been noted that renal injury resulting from uranium exposure can be diagnosed within days of exposure (ATSDR, 1999). Studies have shown that the solubility of uranium compounds plays a significant role in the amount of damage incurred by the kidney. Inhaled uranium compounds with slow- to medium-dissolution rates are relatively insoluble, and are retained longer in the lungs, thus resulting in lower toxicity to the kidneys and other distal organs. The most obvious effect of uranium exposure is damage to the proximal convoluted tubules (ATSDR, 1999). Additionally, necrotic cells cast from the tubular epithelium in the kidney have been reported in affected animals. Glomerular changes have also been reported in animals exposed to uranium, with severe effects resulting in decreased renal insulin and creatinine clearance (Stopps \& Todd, 1982).

Human renal effects following acute exposure to DU of less than $15 \mathrm{~d}$ includes proteinuria, elevated levels of nonprotein nitrogen (NPN), and abnormal phenol sulfonphthalein excretion. In addition, increased urinary catalase activity and diuresis have also been noted (ATSDR, 1999). McDiarmid et al. 
(2000) reported an increase in a variety of renal function parameters, such as serum creatinine, $\beta_{2}$-microglobulin, retinol binding protein, serum uric acid, urine creatinine, and urine protein in patient veterans. Although $\beta_{2}$-microglobulin concentrations were higher and urine protein concentrations were lower in patients exposed to DU, no significant relationships were found between these parameters in the control and DU-exposed group (McDiarmid et al., 2000).

Several animal studies examined the adverse renal effects of uranium following intermediate exposures of $15 \mathrm{~d}$ to $1 \mathrm{yr}$ (Cross et al., 1981). Effects in hamsters ranged from diuresis, to mild degeneration in the glomerulus and tubules, to proteinuria (Cross et al., 1981). In addition, microscopic lesions in tubular epithelium have been also reported (ATSDR, 1999).

\section{Neurotoxicity}

Despite evidence suggesting a link between neurological toxicity and DU exposure, there are no data demonstrating that excess neurologic disease/mortality risk is associated with uranium exposure. Several human studies have been conducted to determine the neurological effects of uranium exposure. In one report, three individuals were studied after exposure to high concentrations of uranium found in a cloud of soluble uranium compounds (approximately $40-50 \mathrm{mg}$ ) produced by an industrial accident (Moore \& Kathren, 1985). An examination shortly after the accident revealed "mental status changes believed in excess of what would be caused by fear reaction." However, $38 \mathrm{yr}$ after the accident no clinical findings attributable to uranium were found (Moore \& Kathren, 1985; Kathren \& Moore, 1986).

In 1982, a second study examined a 44-yr-old man who had developed foot cramps, leg pain, gait disorder, and a tendency to fall backward after exposure to a bar of metallic uranium that he handled frequently in the first $3 \mathrm{yr}$ of his illness (Goasguen et al., 1982). No exposure estimates are available from this report, but the man's symptoms eventually progressed to an extrapyramidal syndrome with ataxia, nystagmus, and peripheral neuropathy.

McDiarmid et al. (2000) found a statistically significant relationship between elevated DU levels and decreased problematic performance on automated tests assessing performance efficiency and accuracy in Gulf War veterans. However, traditional tests of neurocognitive function, did not show statistical differences. Participants in this study received DU exposure through DU-containing shrapnel wounds. Additional studies at the Baltimore Veterans Administration (VA) Medical Center on veterans exposed to DU fragments found a correlation between poor performance on neurocognitive tests and elevated uranium concentration in the urine (Kane et al., 1998).

Concern over the health of Gulf War veterans has also prompted several animal studies on the neurotoxic effects of DU. Rats receiving oral administration of uranyl acetate $(11-717 \mathrm{mg} \mathrm{U} / \mathrm{kg}$ ) exhibited tremors and acute cholinergic toxicity (Domingo et al., 1987). In animals implanted with DU pellets (as previously described) at three doses (low $=4$ pellets, medium $=10$ pellets, high = 20 pellets), DU was found to cross the blood-brain barrier (Pellmar et al., 1999a). Although DU penetrated the blood-brain barrier, it was not uniformly distributed throughout the brain. In this same report, uranium concentrations in high-dose animals were significantly different from control groups at one and six months after implantation. At 18 mo after implantation, significant accumulations of DU were found in the motor cortex, frontal cortex, cerebellum, midbrain, and vermis. Although the mechanism for this distribution is unknown, the distribution was shown to be dose dependent, with statistical differences observed in the medium- and high-exposure groups (Pellmar et al., 1999a).

In another study, Pellmar et al. (1999b) reported electrophysiological changes in hippocampal slices isolated from rats embedded with DU fragments. Six months after implantation, rats exposed to high-dose DU exhibited significantly smaller population spikes in the CA1 area of the hippocampus compared to controls, but exhibited no changes in synaptic potential. In addition, DU exposure resulted in decreased input/output curves for evoked population spikes, but no changes in input/output curves for amplitude of extracellularly recorded synaptic potentials. The input/output relationships reflect the ability of the synaptic potential to elicit the population spike (E/S coupling). Similar to effects seen at 6 mo after implantation, E/S coupling 12 mo after implantation continued to be significantly impaired in the hippocampal slices of the treated animals. In contrast to results 
seen at 6 mo of exposure, synaptic potential was significantly larger in DU-treated tissue as compared to controls. At $18 \mathrm{mo}$ of exposure, age and uranium effects converged so that differences between control and treatment were not detected. These changes in electrophysiological potential suggest that behavioral and/or neurological deficits could result from prolonged exposures to DU in soldiers with embedded DU-containing shrapnel with respect to learning. Preliminary animal studies failed to demonstrate any performance deficiencies in locomotor activity, discrimination learning, and general functional observations (Pellmar et al., 1999b). Because of the methods used to examine these endpoints might not have been sufficiently sensitive to reveal subtle cognitive effects, the Gulf War Executive Summary recommended further study of cognitive function, neurophysiological responses, and brain DU concentrations in Gulf War veterans (Fulco et al., 2000). Recently, Abou-Donia et al. (2002) reported that intramuscular injection of male rats with lowdose and multiple exposure to uranyl acetate produced prolonged neurobehavioral deficits after the initial exposure ceased.

\section{DNA Damage/Carcinogenicity}

Epidemiological studies indicate a correlation between uranium mining and milling and incidence of DNA-damaging effects resulting in carcinogenesis in humans (Polednak \& Frome, 1981; ATSDR, 1999). There is limited information available assessing the long-term carcinogenic risks associated with embedded DU fragments. McDiarmid et al. (2000) did not find significant differences in the percent of peripheral blood lymphocytes with chromosomal aberrations or sister chromatid exchanges (SCEs) obtained from Gulf War veterans who had embedded DU-containing fragments. Their report, which was performed $7 \mathrm{yr}$ after the veterans' first exposure to DU, noted that the veterans had urinary uranium concentrations ranging from $0.01-30.7 \mu \mathrm{g} / \mathrm{g}$ creatinine (vs. $0.01-0.05 \mu \mathrm{g} / \mathrm{g}$ creatinine in the nonexposed individuals). Since DNA damage is dependent on both dose and duration of exposure, the absence of genotoxic effects may be related to variations in the parameters examined in this study.

Despite the lack of genotoxic effects resulting from DU exposure, the incidence of cancer has increased markedly in Iraq following the Gulf War. There are some areas in southern Iraq that have experienced a two- to fivefold increase in reported cancers. Most of these cases damage the lung, bronchial tubes, bladder, and skin. In addition, increased incidence of stomach cancer in males, and breast cancer in females has also been reported, as well as an overall increase in leukemia cases (Aitken, 1999).

The mutagenic effects of embedded DU pellets were determined in Sprague-Dawley rats which were implanted with 20 pellets of DU or tantalum (Ta) control pellets. Ta is an inert metal widely used in prosthetic devices. The results of this study indicate a time-dependent increase in urine mutagenicity with increasing DU pellets, as assessed by evaluating mutagenic activity in urine using the Ames Salmonella reversion assay. Although the mechanisms for this observation were not discussed, Miller et al. (1998a) suggested that assessing urine mutagenicity might be a useful biomarker to assess the adverse health effects of DU exposure in humans.

A second animal study reported that adult rats having received DU oxide intratracheally cannula (1-3 g uranium oxide powder $/ 10 \mathrm{ml}$ distilled water) did not develop lung tumors, in contrast to rats injected with enriched uranium oxide (Batchelor, 1980). Lung tumors were attributable to the $\alpha$ rays emitted from the enriched oxide, resulting in a nonuniform distribution of radioactivity in the lung.

Other carcinogenicity studies have been completed using in vitro models. In immortalized Chinese hamster ovary $(\mathrm{CHO})$ cells, uranyl nitrate $\left(\mathrm{UNO}_{3}\right)$ decreased the viability of the cells in a concentration-dependant manner $\left(3.0 \times 10^{-3} \mathrm{mM}-3.0 \times 10^{-1} \mathrm{mM}\right)$ (ATSDR, 1999). These concentrations of uranyl nitrate also increased the number of binucleated cells with micronuclei, inhibited cell proliferation, and depressed cell cycle kinetics. Since uranyl nitrate has a high affinity for phosphate, Lin et al. (1993) speculated that the cytotoxic and genotoxic effects might have resulted from the uranyl nitrate binding to phosphate groups on DNA. In a similar study, Miller et al. (1998b) determined that depleted uranium-uranyl chloride $(10 \mu \mathrm{M})$ could transform immortalized human osteosarcoma (HOS) cells to the tumorigenic phenoype. While there was no effect on cell survival or cell 
growth, there was a twofold increase in SCE induction. Furthermore, inoculation of these transformed cells into nude mice resulted in the development of animal tumors within $4 \mathrm{wk}$. The transformation demonstrated in these experiments was characterized by aberrant RAS oncogene expression and tumor suppressor protein expression. Although the mechanisms for this transformation are unknown, Lin et al. (1993) speculated that alterations of specific oncogenes (such as RAS) and/or inactivation of tumor suppressor genes (such as p53 and Rb) by depleted uranium-uranyl chloride might be involved.

Miller et al. (2001) showed that effects of phenyl acetate, a differentiation inducer that affects post-translational processing of RAS, were investigated using HOS cells. Following a $24 \mathrm{~h}$ exposure to DU oxide $(1 \mathrm{mg} / \mathrm{ml})$, cells were incubated from $1 \mathrm{~d}$ to $6 \mathrm{wk}$ with $2.5 \mathrm{mM}$ phenyl acetate. Cells treated

with the phenyl acetate did not exhibit transformation to a tumorigenic phenotype, unlike cells that were not treated with phenyl acetate. Given these findings, the conclusion reached by Miller et al. (2001) is that by targeting the RAS protein pathway, phenyl acetate seems to have potential as an antitumor agent for neoplastic transformation by DU. Recently, Kalinich et al. (2002) reported that depleted uranium in the form of uranyl acetate induced apoptosis in mouse macrophages.

\section{Bone and Musculoskeletal Toxicity}

Bone is considered a critical organ for the concentration of many uranium compounds (Neuman, 1949). Rats implanted intramuscularly with DU pellets (Pellmar et al., 1999b) had the greatest concentrations of DU in bone, specifically tibia and skull. The amount of DU in bone was significantly greater than that seen in control rats implanted with Ta pellets as early as $1 \mathrm{~d}$ and as long as 6,12 , and $18 \mathrm{mo}$ after implantation. Urinary uranium concentrations ranging from $224 \pm 32 \mathrm{ng}$ uranium $/ \mathrm{ml}$ urine were seen in low-dose rats, while $1010 \pm 87 \mathrm{ng}$ uranium $/ \mathrm{ml}$ urine were observed at these high dose rats. These findings suggest that bone is a primary reservoir for intramuscularly embedded DU fragments.

Ubios (1991) observed acutely inhibited periodontal cortical bone formation in rats within $14 \mathrm{~d}$ after a single injection of uranyl nitrate $\left(\mathrm{UNO}_{3}\right)(2 \mathrm{mg} / \mathrm{kg}$ body weight). In addition, chronic intoxication, demonstrated by decreased bone formation and increased bone resorption, was observed 14, 30 , and $60 \mathrm{~d}$ after a single dose $(0.8 \mathrm{mg} / \mathrm{kg}$ body weight) (Miller et al., 2001). Because osteoblasts play a major role in bone resorption, it is possible that uranyl nitrate can directly affect these cells and their precursors by binding to cell membranes. Based on these data, uranium intoxication may be viewed as a potential contributor to osteoporosis or other osteopenic diseases in exposed individuals (Ubios, 1991).

Alveolar wound healing serves as another useful model for the study of bone formation and can be considered a sensitive indicator of bone damage under various experimental conditions (Guglielmotti et al., 1985). Following mandibular molar extraction and postsurgical treatment with $2 \mathrm{mg} / \mathrm{kg}$ body weight uranyl nitrate, it was demonstrated that the alveolar structure in rats was altered as compared to control animals that did not receive uranyl nitrate post-surgically. In animals treated with uranyl nitrate, inhibition of bone formation and impaired healing was assessed using histometrical measurements. Very few newly formed woven trabeculae were seen, and there was little to no bone resorption. Guglielmotti et al. (1985) speculated that acute uranyl nitrate intoxication might induce preosteoblastic and osteoblastic damage, which could be responsible for the observed effects on alveolar wound healing. In a recent study, Miller et al. (2002b) indicated that long term exposure to depleted uranium could produce cancer in humans.

\section{Reproductive Toxicity}

In recent years, it has been shown that uranium is a developmental toxicant when given orally or subcutaneously to mice. Decreased fertility, embryo/fetal toxicity including teratogenicity, and reduced growth of the offspring have been observed following uranium exposure at different gestation periods (Domingo, 2001). Few studies have examined the effects of DU on human reproductive development. Male uranium miners were found to have more firstborn female children than expected (Muller et al., 1967). Moreover, it was reported that some uranium miners exhibited gonadal endocrine system dysfunction, with significant reduction in testosterone (Zaire et al., 1997). 
McDiarmid et al. (2002) reported that semen characteristics of exposed veterans were similar in volume, concentration, morphology, and functional parameters of motility as compared to nonexposed veterans. In this same study, veterans with high urinary uranium were found to have statistically higher concentrations of prolactin. In an assessment of results concerning biological monitoring of Gulf War veterans exposed to depleted uranium, McDiarmid et al. (2002) reported adverse health effects of exposure to uranium on the reproductive and central nervous systems of the exposed veterans. Domingo et al. (1989) reported that perinatal and postnatal exposure of Swiss mice to uranium — as uranyl acetate dihydrate-at daily dosages of $0,0.05,0.5,5$, and $50 \mathrm{mg} / \mathrm{kg}$ from d 13 of pregnancy until weaning of the litters on postnatal d 21 showed significant decreases in the mean litter size on postnatal $d 21$, and in the viability and lactation indices were observed at the $50-\mathrm{mg} / \mathrm{kg} / \mathrm{d}$ dose level.

Bosque et al. (1993) reported that fetal body weight was significantly decreased in mice at 1 and $2 \mathrm{mg} / \mathrm{kg} / \mathrm{d}$ exposure to uranium. They reported the number of total internal and total skeletal defects showed dose-dependent increases at 0.5, 1, and $2 \mathrm{mg} / \mathrm{kg} / \mathrm{d}$. Most morphological defects were developmental variations, whereas malformations were only detected at 1 and $2 \mathrm{mg} / \mathrm{kg} / \mathrm{d}$. Llobet et al. (1991) examined the reproductive toxicity in rats that received 10, 20, 40, or $80 \mathrm{mg} / \mathrm{kg} /$ $\mathrm{d}$ of uranyl acetate $\left(\mathrm{U}\left(\mathrm{C}_{4} \mathrm{H}_{6} \mathrm{O}_{6}\right) \cdot 2 \mathrm{H}_{2} \mathrm{O}\right)$ in the drinking water for $64 \mathrm{~d}$. Exposure resulted in a significant, but non-dose-related, decrease in the reproductive performance of male mice in treated groups. Females who mated with treated males did not show marked differences in number of live and dead fetuses compared with females mated with control males. In addition, testicular function and spermatogenesis were not affected at any dose, as evidenced by normal testes and epididymis weights of treated males compared to control males. Sperm parameters and histopathological examination of the testes also did not reveal any changes between treated and control males. Moderate to severe focal tubular atrophy and interstitial alterations were evident in all dose groups. Vacuolization of Leydig cells was seen in the high-dose treated animals, which may have contributed to a decrease in pregnancy rate. However, uranium treatment for $64 \mathrm{~d}$ may provoke behavioral changes, including decreased libido.

Paternain et al. (1989) examined the effects of oral administration of 5, 10, or $25 \mathrm{mg} / \mathrm{kg} / \mathrm{d}$ of uranyl acetate dihydrate on reproduction. Male mice were treated for $60 \mathrm{~d}$ prior to mating with female mice that had been treated orally for $14 \mathrm{~d}$ prior to mating (Paternain et al., 1989). Female mice continued to receive uranyl acetate throughout mating, gestation, parturition, and nursing of the litters. Treatment demonstrated lethal embryonic effects only at the highest concentration, and growth rate in offspring of exposed females was significantly lower than in control animals. It was concluded that uranium did not produce any adverse effects on fertility, general reproductive parameters, or offspring survival (Paternain et al., 1989). Also in a recent study, Miller et al. (2003) showed that depleted uranium exposure in vitro impacted genomic instability manifested as delayed reproductive death and micronuclei formation.

\section{Pulmonary Toxicity}

Human studies on occupationally-exposed uranium miners have determined that most of the uranium-containing dust inhaled during the mining process does not penetrate the lungs (Morris et al., 1992). Most of the larger uranium particles are deposited in the upper respiratory tract, while particles smaller than $10 \mu \mathrm{m}$ in diameter are deposited in the bronchi and alveoli. In studies focusing on the effects associated with inhaled uranium in miners, no adverse health effects were noted in workers who were exposed to up to $9000-10,000 \mu$ g natural uranium $/ \mathrm{m}^{3}$ (Polednak et al., 1982). Additionally, no increase in overall deaths has been reported due to uranium exposure in mills and metal processing plants (Checkoway et al., 1988).

Cooper et al. (1982) investigated the respiratory effects of acute exposure (less than $15 \mathrm{~d}$ ) to various insoluble uranium compounds, and found severe nasal congestion and hemorrhaging in $100 \%$ of the exposed rats. In an intermediate-exposure study (15d to $1 \mathrm{yr}$ ), these same scientists reported lung lesions, minimal pulmonary hyaline fibrosis, and pulmonary fibrosis in these animals. In addition, Cross et al. (1981) reported slight degenerative changes in the lungs of Syrian golden hamsters as well as pulmonary edema, inflammation of the bronchi, bronchial pneumonia, alveoli and alveolar 
interstices, hyperemia, and atelectasis. Chronic studies with an exposure duration of over $1 \mathrm{yr}$ demonstrated mild pulmonary fibrosis in rats, and lung cancer in dogs (Cross et al., 1981). Furthermore, uranium-induced death has been noted in a rat and guinea pig study by Leach et al. (1970), in which the animals were exposed to $8114 \mathrm{mg} \mathrm{UO}_{3 /} \mathrm{m}^{3}$ for $10 \mathrm{~min}$.

\section{Gastrointestinal Toxicity}

No gastrointestinal effects were noted in animals orally dosed with uranium nitrate in chronic studies using doses up to $644 \mathrm{mg} / \mathrm{kg} / \mathrm{d}$ (Maynard \& Hodge, 1949). In turn, Gilman et al. (1998a, 1998b), who examined rabbits that had been exposed to either 0.96, 4.8, 24, 120, or $600 \mathrm{mg} / \mathrm{L}$ uranyl nitrate hexahydrate for $91 \mathrm{~d}$ in drinking water, did not report adverse effects. Additionally, rats administered as much as $40 \mathrm{mg} / \mathrm{kg} / \mathrm{d}$ of the same uranium compound in a drinking water vehicle for $28 \mathrm{~d}$ showed no signs of dose-dependent histopathological changes (Gilman et al., 1998c).

\section{Hepatic Toxicity}

Although hepatic toxicity has not been classified as a major manifestation of uranium toxicity, some reports have described histological changes following uranium exposure. In addition, there is evidence that uranium may induce lesions in the liver. Lu and Zhao (1990) reported no adverse hepatic effects in a uranium miner who accidentally inhaled powdered uranium tetrafluoride for 5 min. Serum hepatic enzyme concentrations and liver function tests in this patient were reported within normal limits from the time of exposure through a 3-yr follow-up (Lu \& Zhao, 1990).

Cross et al. (1981) reported results from an intermediate-duration exposure study in which fatty livers were found in five of the eight Syrian golden hamsters that died during the study. In addition, focal necrosis of the liver was noted in these same animals. In rabbits exposed to uranium via inhalation at a concentration of $0.13 \mathrm{mg} \mathrm{U} / \mathrm{m}^{3} 8 \mathrm{~h} / \mathrm{d}, 5 \mathrm{~d} / \mathrm{wk}$ for $30 \mathrm{~d}$, urinary catalase activity was increased significantly (Dygert et al., 1949). Although these studies demonstrated some adverse hepatic effects following exposure to uranium, uranium-induced hepatotoxicity has not been a prominent finding in the majority of animal studies that have been completed (ATSDR, 1999).

\section{Dermal Toxicity}

To date, although the potential toxicity of DU and other uranium compounds following dermal exposure has not been assessed in humans (ATSDR, 1999), it has been documented that no human has ever died from dermal exposure to natural uranium.

\section{Toxicity From Embedded DU Fragments}

Exposure to DU fragments is almost exclusively seen in military settings. Since the use of DU munitions has been relatively recent, there is little information available on adverse health effects from humans exposed to embedded DU shrapnel. There has been one ongoing surveillance study examining the health of 33 soldiers presumed to have embedded DU fragments. It was reported that approximately half of the soldiers in the group had elevated 24-h uranium urinary concentrations $7 \mathrm{yr}$ after their first exposure to DU (McDiarmid et al., 2000). Uranium concentrations ranged from $0.01-30.74 \mu \mathrm{g} / \mathrm{g}$ creatinine in DU-exposed veterans to $0.01-0.047 \mu \mathrm{g} / \mathrm{g}$ creatinine in nonexposed veterans. In addition, several perturbations in biochemical and neuropsychological testing have been correlated with exposure to DU-containing fragments. Increased urinary output but no signs of kidney disease or radiation effects were attributed to the chemical toxicity due to DU (McDiarmid et al., 2000).

\section{Immunosuppression/Combined Chemical Toxicity}

There is no evidence supporting immunosuppression as a direct result from exposure only to DU ammunition. However, many soldiers and others deployed in the Persian Gulf during the Gulf War, as well as native Iraqi children, complained of symptoms that seem to reflect an attack on the body's immune system. Included in these complaints are chronic fatigue, rashes, eye and ear infections, hair and weight loss, and coughing (Doucet, 1994). Many of these symptoms were untreatable by 
physicians. Persons known to have been involved in the Gulf War exhibiting these symptoms are diagnosed as having Al Eskan disease, or Desert Storm pneumonitis. Al Eskan disease is a rare condition that seems to be triggered by particles in the exceptionally fine sand dust of the central and eastern Saudi Arabian peninsula. When shells coated with DU hit their intended target, the coating explodes, and the DU becomes part of this fine sand dust. It is hypothesized that inhalation of these DU particulates in the air may be the cause of these symptoms. Saudi Arabian sand was subjected to analysis using scanning electron microscopy, $\mathrm{x}$-ray microanalysis by energy-dispersive spectroscopy, and x-ray photoelectron spectroscopy (Korenyi-Both \& Juncer, 1997). The results of the analyses show that $18 \%$ of the sand particles measured less than $1 \mu \mathrm{m}$ in diameter, a size that can easily be inhaled all the way down to the alveolar sacks and alveoli. Since this area of the respiratory tract is responsible for triggering immune reactions to foreign substances, it seems likely that people who inhaled this dust might have experienced immune-related hyperreactivity. In addition to the small size of the sand, free-floating silicon particles and other organic components were found in the sand, in addition to allergens such as Cladosporium and Alternaria.

\section{Ocular Toxicity}

Following the inhalation of uranyl fluoride, rabbits' eyes became encrusted and exhibited signs of conjunctivitis. Similar effects were observed following the inhalation of uranium tetrachloride. These effects were produced by the uranium vapor or aerosol coming in direct contact with the eye (Orcutt, 1949a). In the same study, acute exposures of rabbits' eyes to uranyl nitrate, uranyl fluoride, uranium trioxide, sodium diuranate, ammonium diuranate, uranium tetrachloride, uranium pentachloride, uranium tetrafluoride, uranium dioxide, uranium peroxide, and uranium tritaoctoxide compounds were assessed. A single, large dose of each compound was instilled into the conjuctival sac of the eye in the form of a dry powder, an aqueous solution, a suspension in lanolin, or a suspension in water. All compounds, with the exception of the oxides, induced varying degrees of eye irritation. Chronic exposure was ascertained only from uranium tetrafluoride $(0.1 \mathrm{~g} / \mathrm{d}$ for $10 \mathrm{~d})$. Inflammation, edema, exudation, and ulceration of the conjuctival sacs occurred, as well as cloudiness, corrosion, and vascularization of the corneas.

\section{Hematological Toxicity}

To date, no human data regarding the effects of DU on hematological parameters has been reported. In rats, a 91-d exposure to uranyl nitrate hexahydrate in drinking water $(0.96,4.8,24$, 120 , or $600 \mathrm{mg}$ uranyl nitrate/L) was shown to alter several hematological parameters (Gilman et al., 1998c). Both hemoglobin concentrations and red blood cells were significantly increased in females given $24 \mathrm{mg}$ uranyl nitrate/L. Mean corpuscular hemoglobin values were slightly higher in female rats given 24, 120, or $600 \mathrm{mg}$ uranyl nitrate/L. Serum glucose levels were higher in male rats at 24 and $600 \mathrm{mg}$ uranyl nitrate/L. Serum sodium levels were decreased in female rats given $24 \mathrm{mg}$ uranyl nitrate/L. No significant changes were observed in erythrocytes in any of the treatment groups. Despite these observations, there were no trends or dose-related effects on hematological parameters of uranyl nitrate given to rats in drinking water. This study was repeated in New Zealand White rabbits. While there were several changes in hematological parameters, none were dose related (Gilman et al., 1998a). In the same study, inhalation of ammonium diurnate dust $\left(6.8 \mathrm{mg} \mathrm{U} / \mathrm{m}^{3}\right)$ by rats for $6 \mathrm{~h} / \mathrm{d}$ for a total of $30 \mathrm{~d}$ produced a significant decrease in red blood cell count and hemoglobin concentration.

\section{Cardiovascular Toxicity}

Published reports suggest DU exposure produces no adverse effects on cardiovascular function. One male who ingested $15 \mathrm{~g}$ uranyl acetate plus an unknown amount of benzodiazepine in an attempted suicide reported an adverse cardiovascular effect. This dose would be approximately $131 \mathrm{mg}$ uranium/ $\mathrm{kg}$ for a 70-kg man. The patient reported suffering from myocarditis resulting form the uranium ingestion, which ended 6 mo after ingestion (Pavlakis et al., 1996). No cardiovascular effects occurred after an intense accidental inhalation exposure in a man exposed to powdered uranium tetrafluoride for 5 min (Lu \& Zhao, 1990). 
Animal studies also indicated no adverse cardiovascular effects following oral or inhalation exposure to uranium (Dygert et al., 1949). Maynard and Hodge (1949) reported no changes in heart or blood vessels in rats exposed to oral doses as high as $9393 \mathrm{mg}$ uranium $/ \mathrm{kg} / \mathrm{d}$ as uranyl nitrate hexahydrate, $8769 \mathrm{mg}$ uranium $/ \mathrm{kg} / \mathrm{d}$ as uranium tetrachloride, $11,033 \mathrm{mg}$ uranium $/ \mathrm{kg} / \mathrm{d}$ as uranium peroxide, $10,611 \mathrm{mg}$ uranium $/ \mathrm{kg} / \mathrm{d}$ as uranium tetrafluoride, 10,819 $\mathrm{mg}$ uranium $/ \mathrm{kg} / \mathrm{d}$ as uranyl fluoride, $12,342 \mathrm{mg}$ uranium $/ \mathrm{kg} / \mathrm{d}$ as uranium dioxide, $11,650 \mathrm{mg}$ uranium $/ \mathrm{kg} / \mathrm{d}$ as uranium trioxide, or $7859 \mathrm{mg}$ uranium $/ \mathrm{kg} / \mathrm{d}$ as uranyl acetate dihydrate. No adverse cardiovascular effects in rabbits exposed for $91 \mathrm{~d}$ to uranyl nitrate in drinking water $(0.96,4.8,24,120$, or $600 \mathrm{mg} / \mathrm{L})$. Additionally, Wilson et al. (1952) reported no cardiovascular effects in rats exposed to $0.2 \mathrm{mg} \mathrm{U} / \mathrm{m}^{3}$ as uranium hexafluoride for $1 \mathrm{yr}$, and Dygert et al. (1949) found no cardiovascular effects in rats, mice, guinea pigs, and rabbits exposed to $4.8 \mathrm{mg} \mathrm{U} / \mathrm{m}^{3}$ triuranium trioctoxide for $26 \mathrm{~d}$.

\section{RISK ASSESSMENT}

In the United States DU is stored as solid depleted $\mathrm{UF}_{6}$ in metal cylinders at subatmospheric pressure at the three U.S. gaseous diffusion plant sites: Paducah, KY; Portsmouth, OH; and East Tennessee Technology Park, Oak Ridge, TN (Hartmann et al., 2000). Because DU is a heavy metal associated with the various toxicities already described and because it is radioactive, several methods have been developed for assessing the risk of toxicity of humans potentially exposed to depleted $\mathrm{UF}_{6}$. When determining risk assessment for uranium compounds, route of exposure, duration and frequency of exposure, solubility, particle size, reactivity, and molecular weight must all be considered.

The U.S. Environmental Protection Agency (U.S. EPA) recommends an oral reference dose of $0.003 \mathrm{mg}$ uranium $/ \mathrm{kg} / \mathrm{d}$ (U.S. EPA, 2000). The minimal risk level (MLR) for oral exposure developed by the ATSDR is $0.002 \mathrm{mg} / \mathrm{kg} / \mathrm{d}$ for an intermediate duration (15-364 d) (ATSDR, 1999). There are currently no reference concentrations available for evaluating risk assessment of inhaled uranium exposure. Therefore, reference levels for evaluating the health effects of inhalation of uranium compounds have been calculated using route-to-route extrapolation. Using the oral reference dose of $0.003 \mathrm{mg} / \mathrm{kg} / \mathrm{d}$ and assuming a $70-\mathrm{kg}$ man inhales at a rate of $20 \mathrm{~m}^{3 / \mathrm{d}}$ corresponds to an inhalation reference level of $0.011 \mathrm{mg} / \mathrm{m}^{3}$ for soluble uranium compounds. The Occupational Health and Safety Administration (OSHA) has determined the 8-h time-weighted average permissible exposure level (TWA PEL) to be $0.05 \mathrm{mg} / \mathrm{m}^{3}$ for soluble uranium compounds and $0.25 \mathrm{mg} / \mathrm{m}^{3}$ for insoluble uranium compounds (Hartmann et al., 2000).

The chemical health effects assessment hazard index for chronic uranium exposure by the public produced by a hypothetical $\mathrm{UO}_{2}$ conversion facility (a facility that is used to convert depleted $\mathrm{UF}_{6}$ to DU-oxide or metal) has been determined to range from 0.000001 to 0.00005 (Hartmann et al., 2000). A hazard index less than 1 indicates that an exposed person is unlikely to develop adverse health effects. Thus, it is highly unlikely that the general public would be at risk for toxicity due to chronic exposure to DU from conversion facilities.

Reference levels have also been estimated for acute inhalation of uranium associated with accidental releases. The reference level for potential adverse effects of acute exposure to soluble uranium is $10 \mathrm{mg}$ (McGuire, 1991). The reference level for potential irreversible adverse effects (including death or impairment of organ function) due to acute soluble uranium exposure is $30 \mathrm{mg}$ (NRC, 1994). Accordingly, $3 \mu \mathrm{g}$ uranium/g kidney tissue has been determined as the threshold for kidney toxicity corresponding to a single intake of approximately $30 \mathrm{mg}$ soluble uranium by inhalation (Fisher et al., 1991).

Several computer models exist for estimating the downwind dispersion of uranium releases through the air from hypothetical accident locations. These models can simulate accidents produced by natural phenomena such as earthquakes or tornados, process accidents, or storage facility accidents. Such models include HGSYSTEM (Post, 1994a, 1994b) for UF $_{6}$ vapor releases and FIREPLUME (Brown et al., 1997) for UF 6 release from fires (which is particularly useful as chemical accidents typically include fire). 
TABLE 7. Compilation of Current Information Regarding Uranium Toxicity on Various Body Systems

Renal system

Brain/Central Nervous System

DNA

Bone/muscle

Reproductive system

Lungs/respiratory toxicity

Gastrointestinal system

Liver

Skin

Tissues (surrounding embedded DU fragments)

Immune system

Eyes

Blood

Cardiovascular system
Human studies: Elevated levels of protein excretion, urinary catalase and diuresis (McDiarmid et al., 2000).

Animal studies: Damage to Proximal convoluted tubules, necrotic cells cast from tubular epithelium, glomerular changes (ATSDR, 1999;Gilman et al., 1998a, 1998c).

In vitro: None.

Human studies: Decreased performance on neurocognitive tests (McDiarmid et al., 2000).

Animal studies: Acute cholinergic toxicity (Domingo et al., 1987). Dose-dependent accumulation in cortex, midbrain, and vermis.

Electrophysiological changes in hippocampus (Pellmar et al., 1999a,1999b).

Neurobehavioral alterations (Abou-Donia et al., 2002).

In vitro: None.

Human studies: Increased reports of cancers (Aitken, 1999).

Animal studies: Increased urine mutagenicity and induction of tumors (Miller et al., 1998a; Miller et al., 2001).

In vitro: Binucleated cells with micronuclei, Inhibition of cell cycle

kinetics and proliferation (Lin et al., 1993), Sister chromatid induction, tumorigenic phenotype (Miller et al., 1998a).

Human studies: None.

Animal studies: Inhibition of periodontal bone formation (Ubios, 1991) and alveolar wound healing (Gugliemotti et al., 1985).

In vitro: None

Human studies: Uranium minors have more first born female children (Muller et al., 1967).

Animal studies: Moderate to severe focal tubular atrophy; vacuolization of Leydig cells (Llobet et al., 1991).

In vitro: None

Human studies: No adverse health effects reported (Polednak et al., 1982).

Animal studies: Severe nasal congestion and hemorrage, lung lesions and fibrosis, edema and swelling, lung cancer (Cooper et al., 1982; Cross et al., 1981).

In vitro: None

Human studies: Vomiting, diarrhea, albuminuria (Stopps \& Todd, 1982; Wrenn et al., 1985).

Human studies: No effects seen at exposure dose (Lu \& Zhao, 1990).

Animal studies: Fatty livers, focal necrosis (Cross et al., 1981).

In vitro: None.

Human studies: No exposure assessment data available (ATSDR, 1999).

Animal studies: Swollen vacuolated epidermal cells, damage to hair follicles and sebaceous glands (De Rey et al., 1983).

In vitro: None.

Human studies: Elevated uranium urine concentrations (McDiarmid et al., 2000).

Animal studies: Elevated uranium urine concentrations, perturbations in biochemical and neuropsychological testing.

In vitro: None.

Human studies: Chronic fatigue, rash, ear and eye infections, hair and weight loss, cough. May be due to combined chemical exposure rather than DU alone (Korenyi-Both \& Juncer, 1997).

Animal studies: None

In vitro: None

Human studies: None.

Animal studies: Conjunctivitis, irritation inflammation, edema, ulceration of conjunctival sacs (Orcutt, 1949a).

In vitro: None.

Human studies: None.

Animal studies: Decrease in RBC count and hemoglobin concentration.

In vitro: None.

Human studies: Myocarditis resulting from the uranium ingestion, which ended 6 mo after ingestion(Hartmann et al., 2000). No effects (Lu \& Zhao, 1990).

Animal studies: No effects (Maynard \& Hodge, 1949; Gilman et al., 1998a;

Dygert et al., 1949).

In vitro: None. 


\section{CONCLUSIONS}

Recent attention has been given to DU following its widespread use in the Gulf War as it is incorporated into the body through the skin, the respiratory tract, and through oral exposure. Although most of the DU absorbed in the body is metabolized and excreted, enough is distributed throughout the body to raise important toxicological concerns. This review summarizes the known toxicological data of DU on numerous body systems and parameters, and includes in vitro, animal and human studies (Table 7). The long-term effects of DU still have to be definitely resolved, and there is an obvious need for continued studies. The data presented here should serve as impetus for these studies.

\section{REFERENCES}

Abou-Donia, M. B., Dechkovskaia, A. M., Goldstein, L. B., Shah, D. U., Bullman, S. L., and Khan, W. A. 2002. Uranyl acetate-induced sensorimotor deficit and increased nitric oxide generation in the central nervous systems of rats. Pharmacol. Biochem. Behav. 72:881-890.

Abu-Qare, A. W., and Abou-Donia, M. B. 2001. Determination of depleted uranium, pyridostigmine bromide and its metabolite in plasma and urine following combined administration in rats. J. Pharm. Biomed. Anal. 26:281-289.

Abu-Qare, A. W., and Abou-Donia, M. B. 2002. Depleted uranium-The growing concern. J. Appl. Toxicol. 22:149-152.

Agency for Toxic Substances and Disease Registry. 1999. Toxicological profile for uranium (update): Atlanta, GA: Public Health Service.

Aitken, M. 1999. Gulf War leaves legacy of cancer Br. Med. J. 319:401.

Batchelor, A. L. 1980. The carcinogenic effect of localized fission fragment irradiation of rat lung. Int. J. Radiat. Biol. 37:249-266.

Bleise, A., Danesi, P. R., and Burkart, W. 2003. Properties, use and health effects of depleted uranium (DU): A general overview. J. Environ. Radioact. 64:93-112.

Bolton, J. P., and Foster, C. R. 2002. Battlefield use of depleted uranium and the health of veterans. J. Royal Army Med. Corps 148:221-229.

Bosque, M. A., Domingo, J. L., Llobet, J. M., and Corbella, J. 1993. Embryotoxicity and teratogenicity of uranium in mice following subcutaneous administration of uranyl acetate. Biol. Trace. Element Res. 36:109-118

Brown, D., Dunn, W., Policastro, A., and Maloney, D. 1997. FIREPLUME model for plume dispersion from fires: Application to uranium hexafluoride cylinder fires. Argonne National Laboratory. Washington, DC.

Cantaluppi, C., and Degetto, S. 2000. Civilian and military uses of depleted uranium: Environmental and health problems. Ann. Chim. 90:665-676.

Checkoway, H., Pearce, N., Crawford-Brown, D. J., and Cragle, D. L. 1988. Radiation doses and cause-specific mortality among workers at a nuclear materials fabrication plant. Am. J. Epidemiol. 127:255-266.

Clark, D. L., Keogh, D. W., Neu, M. P., and Runde, W. 1997. Uranium and uranium compounds, 4th ed., vol. 24, eds. J. I. Kroschwitz and M. Howe-Grant, pp. 639-694. New York: John Wiley \& Sons.

Cooper, J. R., Stradling, G. N., Smith, H., and Ham, S. E. 1982. The behavior of uranium 233 oxide and uranyl 233 nitrate in rats Int. J. Radiat. Biol. 41:421-433.

Cotton, A. F., Wilkinson, G., Murillo, C. A., and Bochmann, M. 1999. Advanced inorganic chemistry, 6th ed. New York: John Wiley \& Sons.

Cross, F. T., Palmer, R. F., Busch, R. H., Filipy, R. E., and Stuart, B. O. 1981. Development of lesions in Syrian golden hamsters following exposure to radon daughters and uranium dust. Health Phys. 41:1135-1153.

De Rey, B. M., Lanfranchi, H. E., and Cabrini, R. L. 1983. Percutaneous absorption of uranium compounds. Environ. Res. 30:480-491.

Domingo, J. L. 2001. Reproductive and developmental toxicity of natural and depleted uranium: A review. Reprod. Toxicol. 15:603-609.

Domingo, J. L., Llobet, J. M., Tomas, J. M., and Corbella, J. 1987. Acute toxicity of uranium in rats and mice Bull. Environ. Contam. Toxicol. 39:168-174.

Domingo, J. L., Ortega, A., Paternain, J. L., and Corbella, J. 1989. Evaluation of the perinatal and postnatal effects of uranium in mice upon oral administration. Arch. Environ. Health 44:395-398.

Doucet, I. 1994. Desert Storm syndrome: Sick children and dead children? Med. War 10:183-194.

Dygert, H. P., LaBelle, C. W., Laskin, S., Pozzani, U. C., Roberts, E., Rothermel, J. J., Rothstein, A., Spiegl, C. J., Sprague, G. F., and Stokinger, H. E. 1949. Uranium toxicity following inhalation, eds. C. Voegtlin and H. C. Hodge, vol. 1, pp. 423-700. New York: McGraw-Hill.

Ejnik, J. W., Carmichael, A. J., Hamilton, M. M., McDiarmid, M., Squibb, K., Boyd, P., and Tardiff, W. 2000. Determination of the isotopic composition of uranium in urine by inductively coupled plasma mass spectrometry. Health Phys. 78:143-146.

Fisenne, I. M., Perry, P. M., and Welford, G. A. 1980. Determination of uranium isotopes in human bone ash. Anal. Chem. 52:777-779.

Fisher, D., Hui, T., Yorconic, M., and Johnson, J. 1991. Modified biokinetic model for uranium from analysis of acute exposure to UF ${ }_{6}$ Health Phys. 60:335-342.

Fulco, C. E., Liverman, C. T., and Sox, H. C. 2000. Gulf War and health, vol. 1. Washington, DC: National Academy Press.

Gilman, A. P., Villeneuve, D. C., Secours, V. E., Yagminas, A. P., Tracy, B. L., Quinn, J. M., Valli, V. E., and Moss, M. A. 1998a. Uranyl nitrate: 91-Day toxicity studies in the New Zealand white rabbits. Toxicol. Sci. 41:129-137.

Gilman, A. P., Moss, M. A., Villeneuve, D. C., Secours, V. E., Yagminas, A. P., Tracy, B. L., Quinn, J. M., Long, G., and Valli, V. E. 1998 b. Uranyl nitrate: 91-Day exposure and recovery studies in the New Zealand white rabbit Toxicol. Sci. 41:138-151. 
Gilman, A. P., Villeneuve, D. C., Secours, V. E., Yagminas, A. P., Tracy, B. L., Quinn, J. M., Valli, V. E., Willes, R. J., and Moss, M. A. 1998c. Uranyl nitrate: 28-Day and 91-day toxicity studies in the Sprague-Dawley rat. Toxicol. Sci. 41:117-128.

Gladney, E. S., and Rook, H. L. 1975. Simultaneous determination of tellurium and uranium by neutron activation analysis. Anal. Chem. 47:1554-1557.

Goasguen, J., Lapresle, J., Ribot, C., and Rocquet, G. 1982. Chronic neurological syndrome resulting from intoxication with metallic uranium Nouv. Presse. Med. 11:119-121.

Grey, C. A. 1993. Uranium: From ore to concentrate Nucl. Eng. 34:3-9.

Guglielmotti, M. B., Ubios, A. M., and Cabrini, R. L. 1985. Alveolar wound healing alteration under uranyl nitrate intoxication. J. Oral Pathol. Med. 14:565-572.

Hartmann, H. M., Monette, F. A., and Avci, H. I. 2000. Overview of toxicity data and risk assessment methods for evaluating the chemical effects of depleted uranium compounds. Hum. Ecol. Risk Assess. 6:851-874.

Hodge, S. J., Ejnik, J., Squibb, K. S., McDiarmid, M. A., Morris, E. R., Landauer, F., and McClain, D. E. 2001. Detection of depleted uranium in biological samples from Gulf War veterans. Mil. Med. 166(12 suppl.):69-70.

Hursh, J. B., Weuman, W. R., Toribara, T., Wilson, H., and Waterhouse, C. 1969. Oral ingestion of uranium by man. Health Phys. 17:619-621.

ICRP. 1994. Human respiratory tract model for radiological protection. Ann. ICRP 24(1-3). Elmsford, NY: Permagon Press.

Kalinich, J. F., Ramakrishnan, N., and McClain, D. E. 2000. A procedure of the rapid detection of depleted uranium in metal shrapnel fragments. Mil. Med. 165:626-629.

Kalinich, J. F., Ramakrishnan, N., Villa, V., and McClain, D. E. 2002. Depleted uranium-uranyl chloride induces apoptosis in mouse macrophages. Toxicology 179:105-114.

Kane, R. L., DiPino, R. K., Kabat, M. H., Kaup, B., Hooper, F., Keogh, J., and McDiarmid, M. A. 1998. [Federally sponsored Gulf War Veterans' Illnesses Research Program] Neurocognitive findings in soldiers wounded with depleted uranium shrapnel. Obtained from US Department of Veterans Affairs, Washington, DC.

Kathren, R. L., and Moore, R. H. 1986. Acute accidental inhalation of U: A 28 year follow-up. Health Phys. 51:609-619.

Korenyi-Both, A. L., and Juncer, D. J. 1997. Al Eskan disease: Persian Gulf syndrome Mil. Med. 162:1-13.

Krystek, P., and Ritsema, R. 2002. Determination of uranium in urine-measurement of isotope ratio quantification by use of inductively coupled plasma mass spectrometry. Anal. Bioanal. Chem. 374:226-229.

Lide, D. R. 1994. Uranium, 74th ed., pp. 31-32. Boca Raton, FL: CRC Press.

Lin, R. H., Wu, L. J., Lee, C. H., and Lin-Shiau, S. Y. 1993. Cytogenetic toxicity of uranyl nitrate in Chinese hamster ovary cells. Mut. Res. 319:197-203.

Llobet, J. M., Sirvent, J. J., Ortega, A., and Domingo, J. L. 1991. Influence of chronic exposure to uranium on male reproduction in mice. Fundam. Appl. Toxicol. 16:821-829.

Lu, S., and Zhao, F.-Y. 1990. Nephrotoxic limit and annual limit of intake for natural uranium. Health Phys. 58:619-623.

Maynard, E., and Hodge, H. 1949. Studies of the toxicity of various uranium compounds when fed to experimental animals, eds. C. Voetglin and H. C. Hodge pp. 309-376. New York: McGraw-Hill.

McDiarmid, M. A., Keogh, J. P., Hooper, F. J., McPhaul, K., Squibb, K., Kane, R., DiPino, R., Kabat, M., Kaup, B., Anderson, L., Hoover, D., Brown, L., Hamilton, M., Jacobson-Kram, D., Burrows, B., and Walsh, M. 2000. Health effects of depleted uranium on exposed Gulf War veterans. Environ. Res. 82:168-180.

McDiarmid, M. A., Hooper, F. J., Squibb, K., McPhaul, K., Engelhardt, S. M., Dipino, R., and Kabat, M. 2002. Health effects and biological monitoring results of Gulf War veterans exposed to depleted uranium. Mil. Med. 167:123-124.

McGuire, S. 1991. Chemical toxicity of uranium hexafluoride compared to acute effects of radiation NUREG-1391. U.S. Nuclear Regulatory Commission, Office of Nuclear Regulatory Research. Washington, DC.

Miller, A. C., Fuciarelli, A. F., Jackson, W. E., Ejnik, E. J., Emond, C., Stroko, S., Hogan, J., Page, N., and Pellmar, T. 1998a. Urinary and serum mutagenicity studies with rats implanted with depleted uranium or tantalum pellets. Mutagenesis 13:643-648.

Miller, A. C., Blakly, W. F., Livengood, D., Whittaker, T., Xu, J., Ejnik J. W., Hamilton, M. M., Parlette, E., St. John, T., Gerstenberg, H. M., and Hsu, H. 1998b. Transformation of human osteoblast cells to the tumorigenic phenotype by depleted uranium-uranyl chloride. Environ. Health Perspect. 6:465-471.

Miller, A. C., Xu, J., Stewart, M., and McClain, D. 2001. Suppression of depleted uranium-induced neoplastic transformation of human cells by the phenyl fatty acid, phenyl acetate: Chemoprevention by targeting the p21RAS protein pathway Radiat. Res. 155:163-170.

Miller, A. C., Stewart, M., Brooks, K., Shi, L., and Page, N. 2002a. Depleted uranium-catalyzed oxidative DNA damage: Absence of significant alpha particle decay. J. Inorg. Biochem. 91:246-252.

Miller, A. C., Xu, J., Stewart, M., Prasanna, P. G., and Page, N. 2002b. Potential late health effects of depleted uranium and tungsten alloy armor-piercing munitions: Comparison of neoplastic transformation genotoxicity with known carcinogen nickel. Mil. Med. 167:120-122.

Miller, A. C., Brooks, K., Stewart, M., Anderson, B., Shi, L., McClain, D., and Page, N. 2003. Genomic instability in human osteoblast cells after exposure to depleted uranium: Delayed lethality and micronuclei formation. J. Environ. Radioact. 64:247-259

Moore, R. H., and Kathren, R. L. 1985. A World War II uranium hexafluoride inhalation event with pulmonary implications for today. J. Occup. Environ. Med. 27:753-756.

Morris, K. J., Barker, C. L., Batchelor, A. L., and Khanna, P. 1992. Dosimetric implications of pulmonary macrophage clusters observed within lungs of rats that have inhaled enriched $\mathrm{UO}_{2}$ particles. Environ. Health Perspect. 97:201-208.

Muller, C., Ruzicka, L., and Bakstein, J. 1967. The sex ratio in the offspring of uranium miners Acta Univ. Carolinae Med. 13:599-603.

National Research Council. 1994. Certification of gaseous diffusion plants final rule. Discussion on Section 76.85. Assess. Accidents 59:48944. 
Neuman, W. F. 1949. The distribution and excretion of uranium complexes, eds. K. Voegtlin and H. C. Hodge, vol. 1, pp. 701-728. New York: McGraw-Hill.

Orcutt, J. A. 1949a. The toxicology of compounds of uranium following application to the eye, eds. K. Voegtlin and H. C. Hodge, vol. 1, pp. 415-422. New York: McGraw-Hill.

Orcutt, J. A. 1949b. The toxicology of compounds of uranium following application to the skin, eds. K. Voegtlin and H. C., Hodge, vol. 1, pp. 376-414. New York: McGraw-Hill.

OSAGWI. 1998. Depleted uranium in the Gulf. Washington, DC: U.S. Department of Defense, Office of the Special Assistant for Gulf War Illness.

Oskarsson, A., Hallen, I. P., Sundberg, J., and Grawe, K. P. 1998. Risk assessment in relation to neonatal metal exposure. Analyst 123:19-23.

Papastefanou, C. 2002. Depleted uranium in military conflicts and the impact on the environment. Health. Phys. 83:280-282.

Paternain, J. L., Domingo, J. L., Ortega, A., and Llobet, J. M. 1989. The effects of uranium on reproduction, gestation, and postnatal survival in mice. Ecotoxicol. Environ. Safety 17:291-296.

Pavlakis, N., Pollock, C. A., McLean, G., and Bartrop, R. 1996. Deliberate overdose of uranium: Toxicity and treatment Nephron 72:313-317.

Peehs, M., Walter, T., and Walter, S. 1996. Uranium, uranium alloys, and uranium compounds, 5th ed., eds. B. Elvers and S. Hawins, vol. 27, pp. 281-332. Deerfield Beach, FL: VCH.

Pellmar, T. C., Fuciarelli, A. F., Ejnik, J. W., Hamilton, M., Hogan, J., Strocko, S., Emond, C., Mottaz, H. M., and Landauer, M. R. 1999 a. Distribution of uranium in rats with depleted uranium pellets. Toxicol. Sci. 49:29-39.

Pellmar, T. C., Keyser, D. O., Emery, C., and Hogan, J. B. 1999b. Electrophysiological changes in hippocampal slices isolates from rats embedded with depleted uranium fragments Neurotoxicology 20:785-792.

Polednak, A. P., and Frome, E. L. 1982. Mortality among men employed between 1943 and 1947 at a uranium-processing plant J. Occup. Environ. Med. 23:169-178.

Polednak, A. P., Keane, A. T., and Beck, W. L. 1982. Estimation of radiation doses to the lungs of early uranium processing plant workers Environ. Res. 28:313-328.

Post, L. 1994a. HGSYSTEM 3.0, User's manual. Shell Research Limited. Chester, England.

Post, L. 1994b. HGSYSTEM3.0, Technical reference manual. Shell Research Limited. Chester, England.

Soloveichik, G. L. 1993. Actinides: Inorganic \& coordination chemistry, vol. 1, pp 2-19. New York: Chapman \& Hall, Scientific Data Division.

Stopps, G. J., and Todd, M. 1982. The chemical toxicity of uranium with special reference to effects on the kidney and the use of urine for biological monitoring. Atomic Energy Control Board. Ottawa, Canada.

Stradling, G. N., Stather, J. W., Gray, S. A., Moody, J. C., and Hodgson, A. 1989. The metabolic behaviour of uranium octoxide bearing residues after their deposition in the rat lung: The implications for occupational exposure Exp. Pathol. 37:76-82.

Stuart, W. I., Adams, R. B., and Smith, H. E. 1979. Solubility and hemolytic activity of uranium trioxide Environ. Res. 18:385-396.

Ubios, A. M. 1991. Uranium inhibits bone formation in physiologic alveolar bone modeling and remodeling. Environ. Res. 54:17-23.

U.S. Environmental Protection Agency. 1991. National primary drinking water regulations: Radionucleotides; proposed rule. Fed. Reg. 56.

U.S. Environmental Protection Agency. 2000. Substance file for uranium, soluble salts. Office of Research and Development, National Center for Environmental Assessment. Washington, DC.

Uyttenhove, J., Lemmens, M., and Zizi, M. 2002. Depleted uranium in Kosovo: Results of a survey by gamma spectrometry on soil samples. Health Phys. 83:543-548.

Wilson, H. B., Sylvester, G. E., Laskin, S., Labelle, C. W., Scot, B., and Stokinger, H. E. 1952. Relation of particle size of uranium dioxide dust to toxicity following inhalation by animals; II. AMA Arch. Ind. Hyg. Occup. Med. 6:93-104.

Wrenn, M. E., Durbin, P. W., Howard, B., Lipsztein, J., Rundo, J., Still, E. T., and Willis, D. L. 1985. Metabolism of ingested U and Ra. Health Phys. 48:601-633.

Zaire, R., Notter, M., Riedel, W., and Thiel, E. 1997. Unexpected rates of chromosomal instabilities and alterations of hormone levels in Namibian uranium miners. Radiat. Res. 147:578-584. 
